\title{
Analysis of groundwater level trend and groundwater drought using Standard Groundwater Level Index: a case study of an eastern river basin of West Bengal, India
}

\author{
Sudipa Halder ${ }^{1}$. Malabika Biswas Roy ${ }^{2}$ Pankaj Kumar Roy ${ }^{1}$
}

Received: 3 December 2019 / Accepted: 18 February 2020 / Published online: 28 February 2020

(c) Springer Nature Switzerland AG 2020

\begin{abstract}
Global water demand has far exceeded the total available water resources which in turn have put a serious concern on food security. Changes in the land use and land cover scenario and rapid population growth are putting unavoidable stress over the water resources of the nation. The Indian aquifer system is facing an acute crisis due to the unscientific abstraction of groundwater for agricultural, industrial and domestic sector by the 1.3 billion growing population. To investigate the groundwater degradation, 20 wells from a river basin of West Bengal have been selected to study their seasonal groundwater level trend using Mann-Kendall test statistics from 1996 to 2018 where $60 \%$ of the wells are showing a decline in water level particularly in post-monsoon season. These wells are mainly located near the agricultural land where extraction of groundwater from submersible pumping wells is extensive as observed from socio-economic survey. Agglomerated hierarchical cluster analysis has been executed to classify the wells based on their magnitude of fluctuation. The wells have been classified in four clusters where cluster I consists most of the wells about 15 numbers whose fluctuation ranged between 1.8 and $4.33 \mathrm{~m}$ below groundwater level (mbgl). Finally, Standard Groundwater Level Index has been applied to understand the groundwater drought years. Well locations like Simlapal, Bheduasol and Neradeul have a higher frequency of drought years. The recharge potential of the wells is now decreasing day by day. Such kind of studies is required and will help the stakeholders to focus on sustainable management of this valuable water resource.
\end{abstract}

Keywords Mann-Kendall · Hierarchical clustering · Groundwater level · Groundwater drought

\section{Introduction}

Groundwater is an important source of freshwater reserve where billions of habitants solely depend for their diverse utilisation. Groundwater crisis in the recent years has become a global concern as its vulnerability increased with greater frequency and magnitude. One of the prime causes of the shortage of groundwater storage and a decline in water level is climate change together with extensive extraction of groundwater from the shallow aquifer for agriculture, industry and other domestic purpose. Drying up of the river bed leads to poor discharge or infiltration into the sub-surface layer therefore sustaining the river stage, and health is in current need. In recent years, global warming together with climate change has led to the deficit of precipitation and an increase in evapotranspiration through a temperature rise directly influencing the recharge of a region. Variability of precipitation, temperature and evapotranspiration as predicted from

Electronic supplementary material The online version of this article (https://doi.org/10.1007/s42452-020-2302-6) contains supplementary material, which is available to authorized users.

Pankaj Kumar Roy, pk1roy2014@gmail.com; pk1roy@yahoo.co.in; Sudipa Halder, sudipa.halder92@gmail.com; Malabika Biswas Roy, malabikabiswasroy@gmail.com | ${ }^{1}$ School of Water Resources Engineering, Jadavpur University, Kolkata 700032, India. ${ }^{2}$ Women's College, Calcutta, Kolkata 700003, India. 
various climate change scenarios will affect the aquifers which depend on physical properties of recharge areas [1]. Recharge in the arid and semi-arid regions sometimes changes due to the minimal changes in the precipitation volume [1]. The rise in mean global temperature will have a $30 \%$ decrease in groundwater recharge for $4 \%$ of the land area and $70 \%$ of the decrease in recharge in $1 \%$ of the land area globally [2]. Thus, vivid understanding of the impacts of climate change on global hydrological cycle including groundwater should be clear to undertake adaptation strategies [3]. This scenario of groundwater shortage can be termed as groundwater drought. The groundwater drought has an adverse effect on public, agricultural and industrial water supply as well as on groundwater-dependent ecosystem and water bodies [4]. According to Zekter and Everett [5], about $50 \%$ of the domestic water, $40 \%$ of the industrial supply and $20 \%$ of the irrigation supply are mainly sourced from groundwater. Thus, with an increase in the population density, the groundwater recharge as well as level will decrease more in shallow aquifer [6]. Since the twentieth century, the groundwater extraction explosively increased around the world. According to a database of 2010, the groundwater extraction is about $1000 \mathrm{~km}^{3} /$ year and the major consumers are from Asia including India, China, Pakistan, Bangladesh and extraction rate has been tripled over the 50 years and still rising [7]. Major parts of the Indian aquifer system are showing a declining trend due to alteration in the pattern of precipitation. The emergence of the modern pumping system and electrification in rural areas has led to the increase in groundwater extraction from $312 \mathrm{~km}^{3} /$ year in 1960 s to about $743 \mathrm{~km}^{3} /$ year in 2000 [8]. Sustainable management of the groundwater resources is now challenging and complex in the areas of climate change and extensive anthropogenic activities; thus, modern tool and decisions are needed to sustain long-term groundwater extraction strategies [9]. Engelenburg et al. [3] applied hydrological modelling to study the projected impact of climate in Veluwe aquifer of the Netherland to observe the effect of extensive groundwater extraction on groundwater-dependent ecosystem nearby. Salem et al. [10] studied the impact of climate change in irrigation cost for a groundwater-dependent region of North-West Bangladesh by using general circulation model and hydrological model based on support vector machine to simulate the ground water level from meteorological variables. Before the simulation of groundwater level, analysis of present and future trend through evaluation of past data is needed. Sishodia et al. [11] analysed groundwater trend of 23 wells of a crystalline aquifer in semi-arid South India to observe whether the trends are due to physical or non-physical factors. Tiwari el al. [12] employed GRACE satellite data and groundwater level to observe the groundwater storage in Andhra Pradesh and found an overall increase which may be due to inter-annual variability of rainfall. Kumar and Rathnam [13] applied four variations of Mann-Kendal and auto-regressive integrated moving average (ARIMA) for prediction and trend analysis of 40 observational wells of Warangal district and found three wells showing positive trend and another 37 wells showing a negative trend. Positive trends in the groundwater level are a serious concern and need supervision at an early stage. A positive trend means a decrease in groundwater level below surface level and such can be due to poor recharge because of changes in land use and land cover of a particular region. Rapid urbanisation and increase in built-up areas increase the fluctuation of groundwater level due to environmental degradation and concretion of soil surface. Patra et al. [14] applied Normalised Built-up Index and estimated the land use and land cover change to identify the effects of extensive urban sprawl on groundwater recharge. Based on the trend analysis, groundwater level and recharge pattern of wells can be grouped into numerous clusters to manage them specifically. Pathak and Dodamani [15] applied hierarchical clustering method to group the fluctuation level of the wells in the Ghataprabha river basin of India and found that the cluster 1 and cluster 3 wells have high fluctuation due to groundwater drought. Ganapuram et al. [16] conducted a study to identify spatio-temporal groundwater drought and drought-prone regions using Standard Water Level Index and spline interpolation in geographical information system. Bloomfield et al. [17] studied groundwater drought in the chalk aquifer of the UK and found evapotranspiration associated with anthropogenic activities is the prime reason inducing the changing nature of drought. But till date, studies related to groundwater drought are fewer in number, but this situation needs a strategic longterm action plan.

In India, according to Central Ground Water Board (CGWB) report of 2017-2018 [18], the overall stage of groundwater extraction increased from 62 to $63 \%$. The over-exploited regions of India are parts of Punjab, Haryana and Delhi where indiscriminate withdrawal has been observed. According to CGWB, the annual replenishable groundwater resources were 432 billion cubic metres (BCM), net annual groundwater availability is also $393 \mathrm{BCM}$, and annual groundwater draft is about 249 BCM. According to the report, $60 \%$ of the wells in India witnessed a declining trend in water level. Recent drying up of the water bodies due to an increase in the magnitude of the temperature graph in the parts of West Bengal, India, particularly in the districts of Bankura, Puruliya and West Medinapore led to the decline of water level in wells. Agricultural practice here solely depends on the extraction of groundwater through submersible pumping sets from shallow aquiferous system leading to further decline in the water level. Land use and land cover change has also put a significant effect on the recharge pattern over the regions. Theeffects of the southwest monsoon show poor recharge and slow increase in the post-monsoon water level due to poor precipitation consistency. No comprehensive scientific assessment of groundwater wells has been done over the selected river basin under study. 
Thus, the objective of the study includes (1) to analyse the groundwater level variability through seasonal (pre-monsoon, monsoon and post-monsoon) trend analysis using nonparametric statistical method of Mann-Kendall test for 20 wells within the study area, (2) to understand the impact of land use and land cover change of each of the well location to visualise the controlling factor for groundwater recharge, (3) application of agglomerated hierarchical cluster analysis (HCA) to group the wells based on fluctuation scenario and lastly (4) to understand the impact of climatological variability on water level or groundwater drought by using the Standard Groundwater Level Index for three seasons from 1996 to 2018. Such studies will incur valuable information and will give a reflection of the groundwater scenario of the basin to the stakeholders and policy makers for sustainable water resources management.

\section{Study area}

The Shilabati river basin is an important eastern river basin of West Bengal, India, which originates from Chotonagpur Plateau in Puruliya district of West Bengal and flows in a south-easterly direction through the districts of Bankura, West Medinapore, and joins Rupnarayan River at Ghatal block of West Medinapore, West Bengal, India. The river is positioned between $23^{\circ} 32^{\prime} \mathrm{N}$ to $23^{\circ} 14^{\prime}$ latitude and $86^{\circ} 40^{\prime} \mathrm{E}$ to $87^{\circ} 46^{\prime}$ E longitude (Fig. 1). The elevation of the basin varies from 212 to 4 mean sea level (MSL). The total catchment area is about $3881 \mathrm{~km}^{2}$. The river is divided into eight sub-basins, namely Donai, Tamal, Kubai, Joy Panda, Parang, Purandar, Silai and Betal. The study area falls under semi-arid-to-humid climatic condition and receives an average monthly rainfall

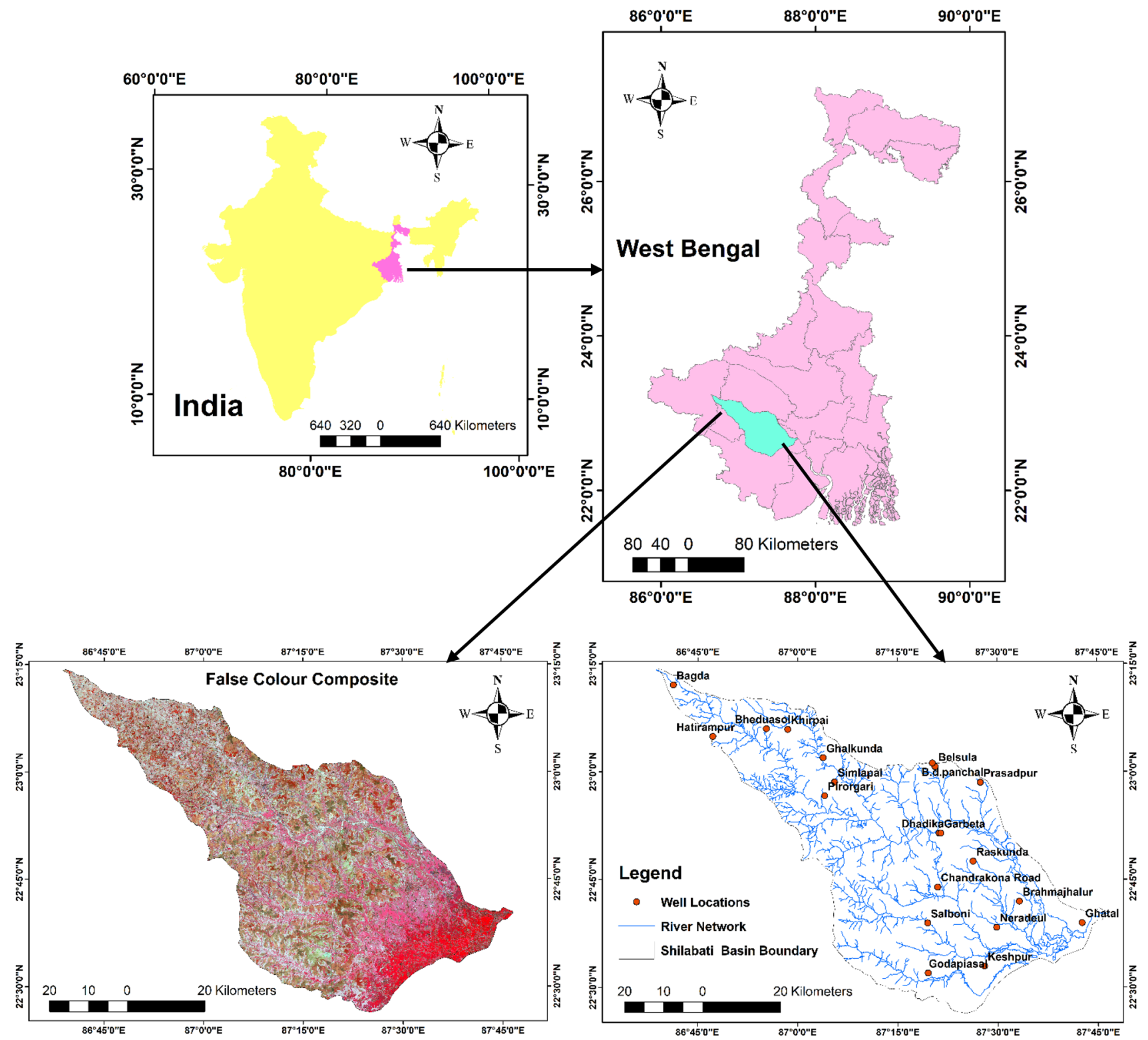

Fig. 1 Location of the study area 
of $107 \mathrm{~mm}$ which is mainly concentrated in the monsoon season. The main land use and land cover of the region is agriculture and irrigation which are mainly practised using groundwater where extraction occurs through the shallow submersible pumping set. The study area covers three different terrain conditions that is undulating hard rock terrain at the upper section, lateritic terrain in the middle and the lower section is alluvial in origin. Here, water bodies dry up every year mainly in the summer season during which people depend on the groundwater for various activities and worsen the situation [19] which makes it inevitable to evaluate the groundwater resource available within the region.

\section{Materials and methods}

\subsection{Date source}

In order to fabricate the groundwater resource assessment, ground water level data of 20 monitoring wells (Fig. 1) have been downloaded from Central Groundwater Board, Government of India, for the period of 22 years (1996-2018) of three different seasons that is pre-monsoon, monsoon and

Table 1 Information of data acquired

\begin{tabular}{lll}
\hline Date of acquisition & Path and row & Satellite \\
\hline 23.03 .1989 & $139 / 44$ & Landsat 5 \\
29.03 .2000 & $139 / 44$ & Landsat 7 \\
30.03.2009 & $139 / 44$ & Landsat 5 \\
20.03 .2018 & $139 / 44$ & Landsat 8 OLI \\
\hline
\end{tabular}

post-monsoon. Gridded monthly rainfall data of TRMM 3 B 43 $\left(0.25^{\circ} * 0.25^{\circ}\right)$ have been downloaded for the GESDISC Web site (https://disc.gsfc.nasa.gov/) for the year 1998-2018. Land use and land cover classification maps have been prepared using Landsat images for four different years that are 1989, 2000, 2009 and 2018. The satellite images have been downloaded from UGSC Earth Explorer (https://earthexplo rer.usgs.gov/) for path of 139 and row of 44 (Table 1). The locational description based on physical features (Figs. 2, 3, $4,5,6,7$ and 8) of each of the 20 wells has also been made given in a tabular format (Table 2). In order to identify the agricultural cropping pattern prevalent in the study area, satellite image of 3 months leading to the cultivation of Rabi (January), Kharif (October) and Zaid (March) has been downloaded from USGS Web site. False Colour Composite of year 1989, 2000, 2009 and 2018 has been prepared, and agricultural land has been extracted for the three different time periods to understand the cropping pattern (Rabi, Kharif and Zaid). The extracted vector of the three images is superimposed to witness the cropping pattern (Fig. 8).

\subsection{Mann-Kendall Test}

Mann-Kendall test is a useful nonparametric statistical analysis to determine spatio-temporal trend within a dataset. The presence of outliers is common within a dataset of extreme events of such a nonparametric Mann-Kendall which is useful as it is based on significance of difference but not on random value [20]. The test has been formulated by Mann-Kendal [21] and is mainly applied while handling environmental time series [22]. In this test, there are two

Fig. 2 Digital elevation model

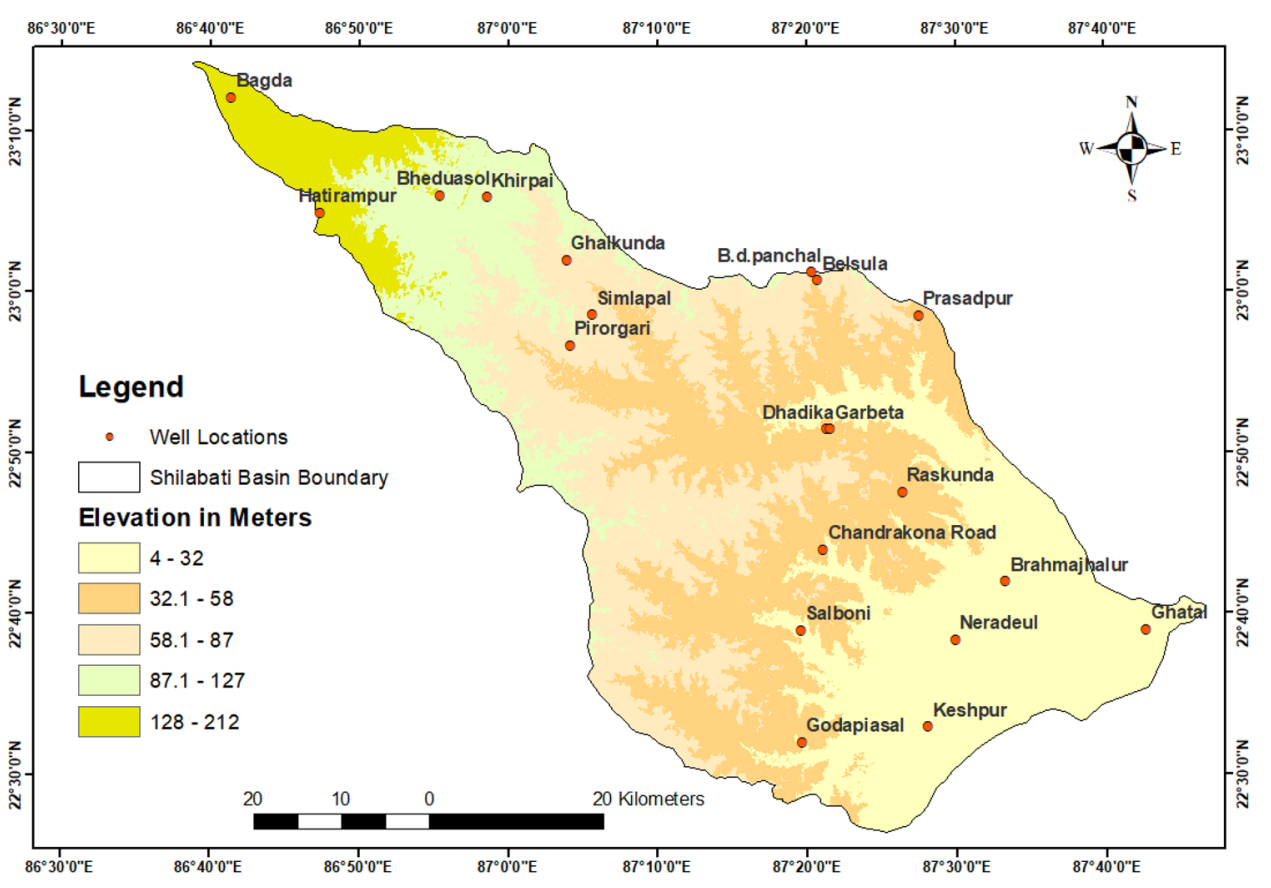

SN Applied Sciences 
Fig. 3 Geology of the study area

Fig. 4 Aquifer depth of the study area
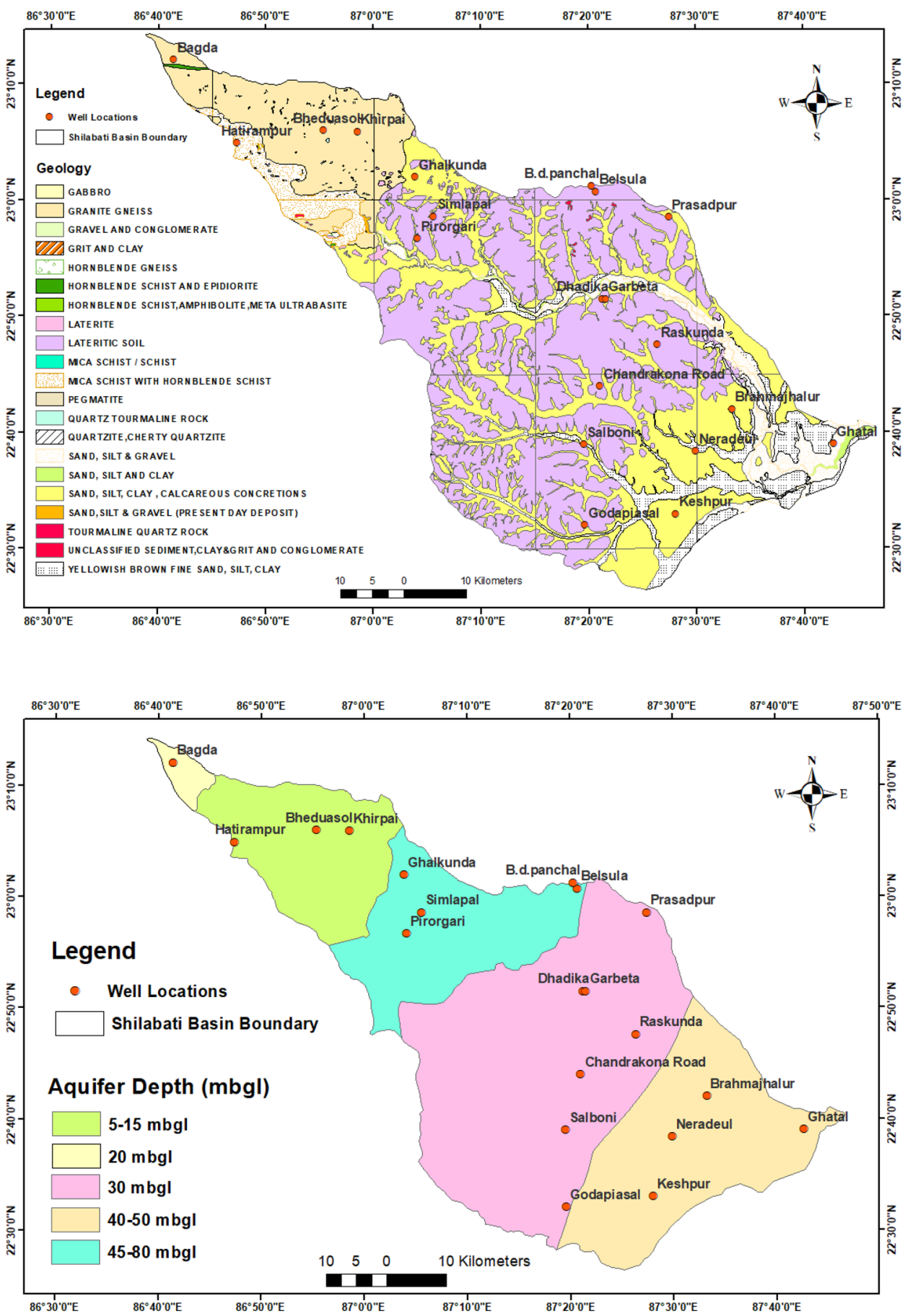

hypotheses: the null hypothesis $\left(H_{\mathrm{o}}\right)$ signifies no trend in the data set and the alternative hypothesis $\left(H_{\mathrm{A}}\right)$ signifies a presence of increasing or decreasing trend within the data set. Here, Mann-Kendall test method has been applied to a long-term (1996-2018) seasonal groundwater level data of pre-monsoon, monsoon and post-monsoon periods for 20 wells to detect statistically significant trend within it. Algorithms used for Mann-Kendall test statistics S, Var and $S=\sum_{i=1}^{n=1} \sum_{j=i+1}^{n} \operatorname{sig}\left(X_{j}-X_{i}\right)$ $\operatorname{Sgn}\left(X_{j}-X_{i}\right)= \begin{cases}+1 & \text { if }\left(X_{j}-X_{i}\right)>0 \\ 0 & \text { if }\left(X_{j}-X_{i}\right) \geq 0 \\ -1 & \text { if }\left(X_{j}-X_{i}\right)>0\end{cases}$ standardised test statistics $Z$ are as follows: 
Fig. 5 Geomorphology of the study area

Fig. 6 Soil map of the study area
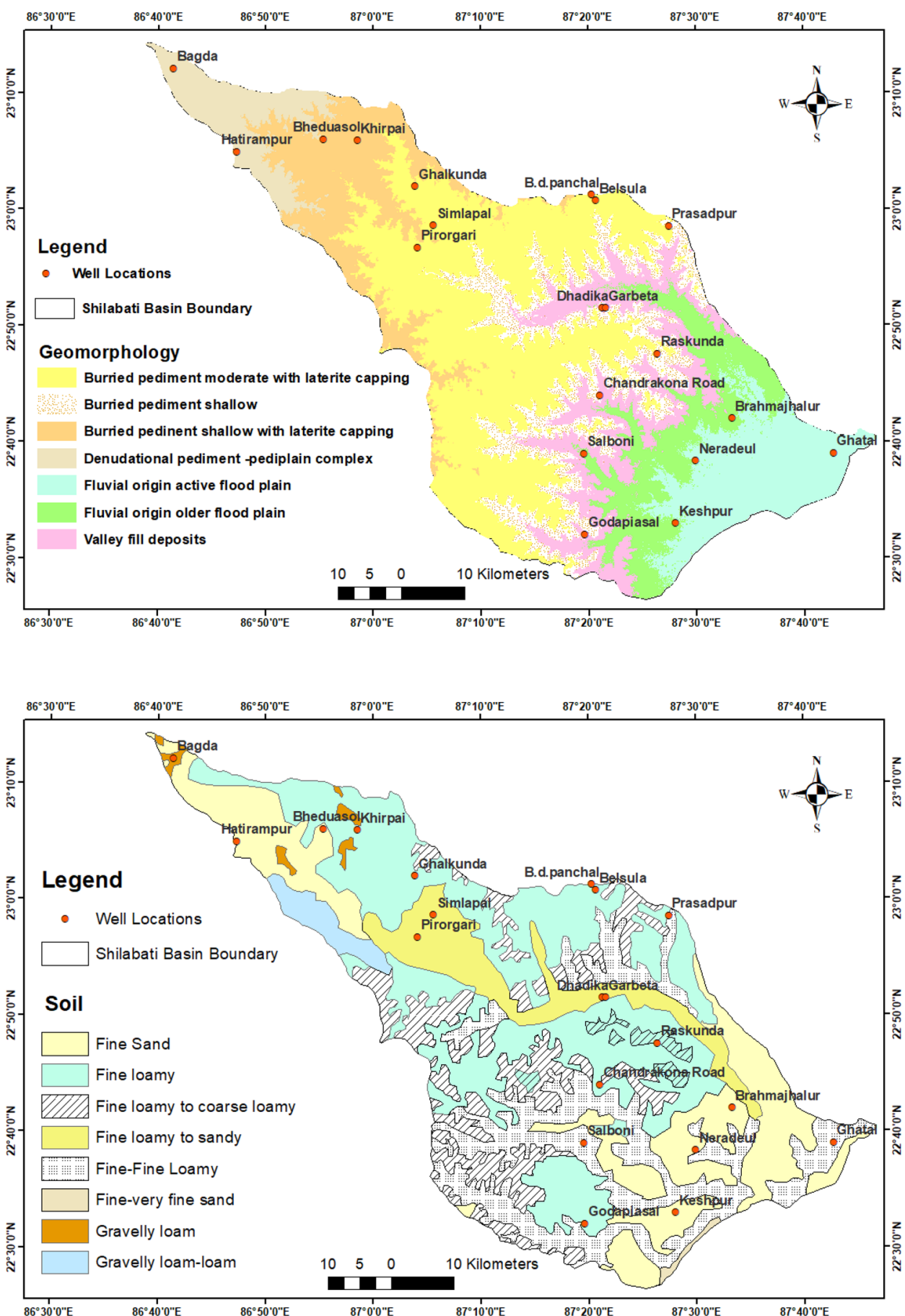

$\operatorname{Var}(S)=1 / 8\left[n(n-1)(2 n+5)-\sum_{P=1}^{\alpha} t_{o}\left(t_{o}-1\right)\left(2 t_{o}+5\right)\right]$

$Z= \begin{cases}\frac{S-1}{\sqrt{\operatorname{VAR}(S)}} & \text { If } S>0 \\ 0 & \text { If } S=0 \\ \frac{S+1}{\sqrt{\operatorname{VAR}(S)}} & \text { If } S<0\end{cases}$
In these equations, $X_{i}$ and $X_{j}$ are the time series monitoring data in sequential order, $n$ is the length of the time series, $t_{o}$ is the number of the tie in the $p$ th value and $m$ is the numbers of tied variables. $V$ is the variance within the data set if $|Z|>Z_{1-\alpha / 2},\left(H_{0}\right)$ is rejected and a significant trend exists within the data. The positive value of the $Z$ means upward rising, and a negative value means downward trend. Here, the test has been performed at a significance level of 0.05 in XLSTAT software. 
Fig. 7 Slope map of the study area

Fig. 8 Cropping pattern of the study area
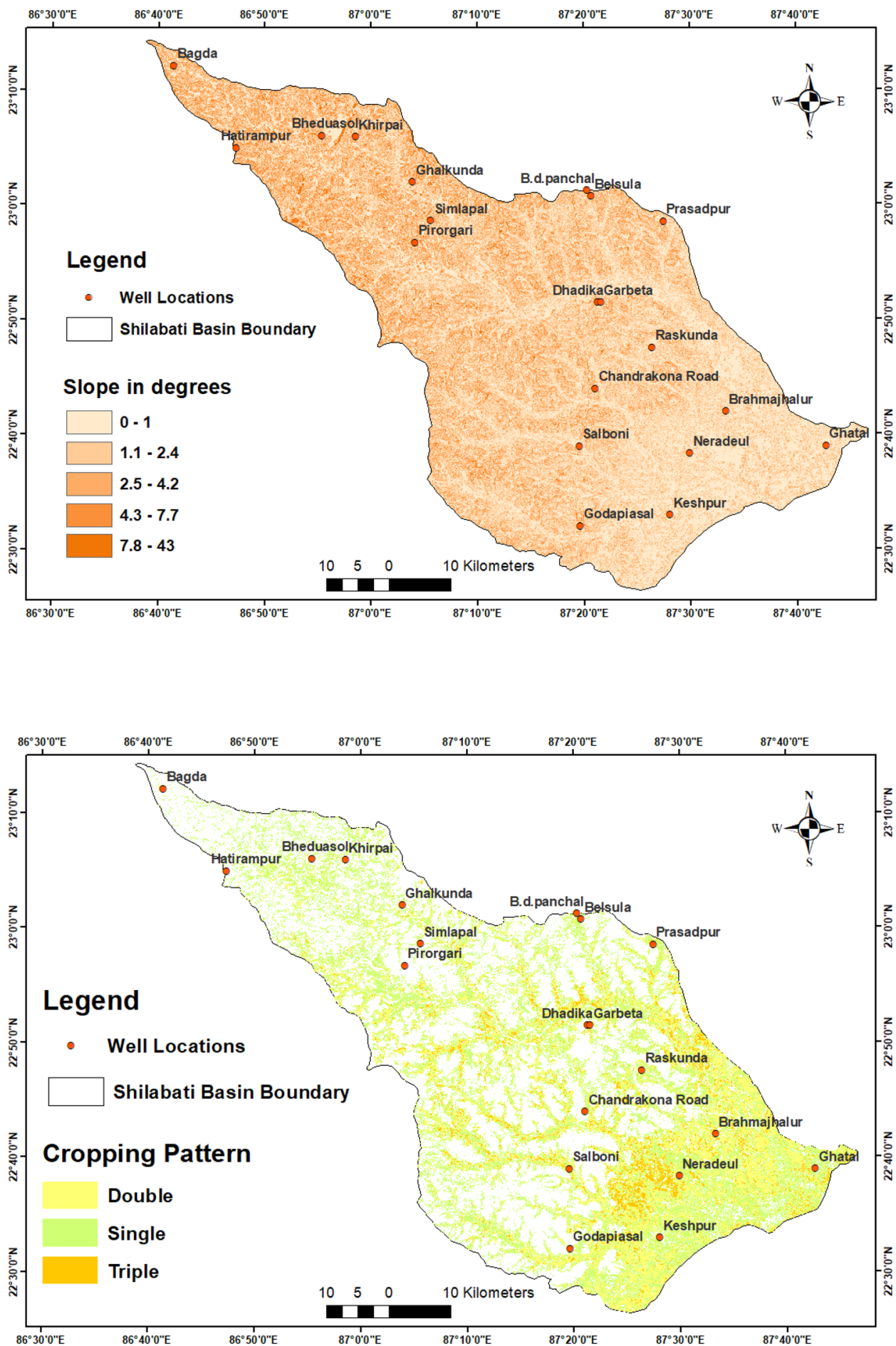

\subsection{Sen's slope estimator}

The magnitude of the trend has been analysed using the Sen's slope estimator as developed by Sen [23]. It has been widely applied in numerous hydro-meteorological time series analyses [24]; here, it has been used to observe the groundwater level trend. The algorithm used in the calculation is given in the following

$$
T_{i}=\frac{x_{i+x_{k}}}{j-k}
$$


Table 2 Locational description of wells

\begin{tabular}{|c|c|c|c|c|c|c|c|}
\hline Parameters & Soil & Geology & Geomorphology & Slope in degrees & Elevation in metres & $\begin{array}{l}\text { Aquifer } \\
\text { depth in } \\
\text { mbgl }\end{array}$ & $\begin{array}{l}\text { Cropping pat- } \\
\text { tern }\end{array}$ \\
\hline $\begin{array}{l}\text { Source } \\
\text { Wells location }\end{array}$ & NBSSLUP & GSI & $\begin{array}{l}\text { Prepared by author based on } \\
\text { different source }\end{array}$ & $\begin{array}{l}\text { SRTM DEM } 30 \mathrm{~m} \\
\text { resolution }\end{array}$ & $\begin{array}{l}\text { SRTM DEM } 30 \text { m } \\
\text { resolution }\end{array}$ & SWID & $\begin{array}{l}\text { Prepared by } \\
\text { author using } \\
\text { RS/GIS }\end{array}$ \\
\hline Badga & Gravelly loam & Granite gneiss & $\begin{array}{l}\text { Denudational pediment-pedi } \\
\text { plain complex }\end{array}$ & 0.14 & 177 & 20 & $\begin{array}{l}\text { Non-cropped } \\
\text { area }\end{array}$ \\
\hline $\begin{array}{l}\text { Chandrakona } \\
\text { road }\end{array}$ & Fine loamy & Laterite & Valley fill deposits & 1.41 & 44 & 30 & Single cropping \\
\hline Brahmajhalur & Fine sand & $\begin{array}{l}\text { Sand, silt, clay, } \\
\text { calcareous } \\
\text { concretions }\end{array}$ & Fluvial origin older flood plain & 0.76 & 20 & $40-50$ & $\begin{array}{l}\text { Double crop- } \\
\text { ping }\end{array}$ \\
\hline Dhadika & $\begin{array}{l}\text { Fine loamy to } \\
\text { sandy }\end{array}$ & Laterite & Buried pediment shallow & 3.62 & 47 & 30 & $\begin{array}{l}\text { Non-cropped } \\
\text { area }\end{array}$ \\
\hline Salboni & Fine-fine loamy & $\begin{array}{l}\text { Yellowish } \\
\text { brown fine } \\
\text { sand, silt, } \\
\text { clay }\end{array}$ & Fluvial origin older flood plain & 1.36 & 27 & 30 & Single cropping \\
\hline Godapaisal & Fine loamy & $\begin{array}{l}\text { Sand, silt and } \\
\text { clay, calcare- } \\
\text { ous concre- } \\
\text { tions }\end{array}$ & Valley fill deposits & 2.60 & 34 & 30 & Single cropping \\
\hline Keshpur & Fine sand & $\begin{array}{l}\text { Sand, silt, clay, } \\
\text { calcareous } \\
\text { concretions }\end{array}$ & Fluvial origin older flood plain & 1.08 & 17 & $40-50$ & $\begin{array}{l}\text { Double crop- } \\
\text { ping }\end{array}$ \\
\hline Neradeul & Fine sand & Laterite & Fluvial origin older flood plain & 0.97 & 16 & $40-50$ & $\begin{array}{l}\text { Non-cropped } \\
\text { area }\end{array}$ \\
\hline Raskunda & Fine loamy & Laterite & Buried pediment shallow & 0.3 & 49 & 30 & Single cropping \\
\hline Belsula & Fine loamy & Laterite & $\begin{array}{l}\text { Buried pediment moderate } \\
\text { with laterite capping }\end{array}$ & 2.16 & 66 & $45-80$ & Single cropping \\
\hline B.D. Panchal & Fine loamy & Laterite & $\begin{array}{l}\text { Buried pediment moderate } \\
\text { with laterite capping }\end{array}$ & 0.34 & 63 & $45-80$ & $\begin{array}{l}\text { Double crop- } \\
\text { ping }\end{array}$ \\
\hline Pirorgari & $\begin{array}{l}\text { Fine loamy to } \\
\text { sandy }\end{array}$ & Laterite & $\begin{array}{l}\text { Buried pediment shallow with } \\
\text { laterite capping }\end{array}$ & 1.23 & 84 & $45-80$ & $\begin{array}{l}\text { Non-cropped } \\
\text { area }\end{array}$ \\
\hline Prasadpur & $\begin{array}{l}\text { Fine loamy to } \\
\text { sandy }\end{array}$ & Laterite & Buried pediment shallow & 1.02 & 49 & 30 & $\begin{array}{l}\text { Double crop- } \\
\text { ping }\end{array}$ \\
\hline Simlapal & $\begin{array}{l}\text { Fine loamy to } \\
\text { sandy }\end{array}$ & Laterite & $\begin{array}{l}\text { Buried pediment moderate } \\
\text { with laterite capping }\end{array}$ & 2.91 & 68 & $45-80$ & Single cropping \\
\hline Khirpai & Fine loamy & Granite genies & $\begin{array}{l}\text { Buried pediment shallow with } \\
\text { laterite capping }\end{array}$ & 2.07 & 115 & $5-15$ & Single cropping \\
\hline Hatirampur & Fine sand & $\begin{array}{l}\text { Mica schist } \\
\text { with Horn- } \\
\text { blende schist }\end{array}$ & $\begin{array}{l}\text { Denudation pediment-pedi } \\
\text { plain complex }\end{array}$ & 1.02 & 164 & $5-15$ & $\begin{array}{l}\text { Double crop- } \\
\text { ping }\end{array}$ \\
\hline Bheduasol & Fine sand & Granitic gneiss & $\begin{array}{l}\text { Buried pediment shallow with } \\
\text { laterite capping }\end{array}$ & 2.41 & 116 & $5-15$ & Single cropping \\
\hline Ghalkunda & Fine loamy & $\begin{array}{l}\text { Sand, silt, clay, } \\
\text { calcareous } \\
\text { concretions }\end{array}$ & $\begin{array}{l}\text { Buried pediment moderate } \\
\text { with laterite capping }\end{array}$ & 3.05 & 84 & $45-80$ & Single cropping \\
\hline Garbeta & $\begin{array}{l}\text { Fine loamy to } \\
\text { sandy }\end{array}$ & Laterite & Valley fill deposits & 1.36 & 39 & 30 & Single cropping \\
\hline Ghatal & $\begin{array}{l}\text { Fine to fine } \\
\text { loamy }\end{array}$ & $\begin{array}{l}\text { Sand, silt and } \\
\text { gravel }\end{array}$ & $\begin{array}{l}\text { Fluvial origin active flood } \\
\text { plain }\end{array}$ & 0.1 & 8 & $40-50$ & Single cropping \\
\hline
\end{tabular}

GSI geological survey of India, SWID state water resources investigation directorate, SRTM shuttle radar topography mission

**NBSSLUP The National Bureau of Soil Survey and Land Use Planning

In this equation, the $X_{i}$ and $X_{k}$ represent the values of the data at the time $j$ and $k$, respectively. Let's consider

$$
Q_{s}= \begin{cases}T_{(N+1) / 2} & N \text { is odd } \\ 1 / 2\left(T_{N / 2}+T_{(N+2) / 2}\right) & N \text { is even }\end{cases}
$$


A positive $Q_{s}$ value represents an increasing trend; a negative $Q_{s}$ value represents a decreasing nature of the trend.

\subsection{Agglomerated hierarchical clustering}

In this study, agglomerated hierarchical clustering (AHC) has been applied to group the wells into the clusters based on the fluctuation pattern with 22-year time period data. It is a method that organises the data according to the hierarchical structures based on proximity matrix [25]. There are two types of hierarchical clustering: one is the agglomerated and another is the divisive method based on how the hierarchical decomposition performed. Here, $\mathrm{AHC}$ has been used which is based on the definition of distance between two clusters. Five types of agglomerative techniques are there which include complete linkage, single linkage, average linkage, median linkage and lastly Ward's linkage method. In this paper, Ward's method has been applied. The whole procedure has been performed using XLSAT.

\subsection{Standard Groundwater Level Index (SGWI)}

The Standard Groundwater level Index is similar to that of the Standard Precipitation Index. It is a quantitative technique for the evaluation of groundwater level deficit in various time scales which signifies or reflects the influence of extreme drought event on the water resources scenario. Based on the SGWI number of drought years, signifying groundwater scarcity and its temporal variation can be observed [15]. Here, SGWI has been calculated for each of the 20 wells from 1996 to 2018 and for each season, i.e. pre-monsoon, monsoon and post-monsoon. SGWI has been calculated using the following equation

$x=\frac{K-M}{\sigma}$

where $K=$ value of the respective year, $M$ is the mean of 22 years, and $\sigma$ is the standard deviation

\section{Results and discussion}

\subsection{Influence of climate variable on groundwater level}

Groundwater recharge of a region depends on the precipitation which infiltrates through the soil surface. Association of groundwater and rainfall is better reflected through hydrograph. The groundwater level is highly sensitive towards the changes in the precipitation scenarios. An increase in the rainfall will lead to the increase in the groundwater well and vice versa. Gridded TRMM rainfall data from 1998 to 2018 have been downloaded, and mean groundwater level of three seasons pre-monsoon, monsoon and post-monsoon for the 20 wells has been shown graphically to understand the association between them. All the graphical figures of the 20 wells have been grouped in one (Fig. 9) where the line shows the groundwater level and bar graph shows rainfall.

Rainfall and groundwater level have been shown graphically from year 1998 to 2018 because of the nonavailability of data from 1996 . The graph shows the spatio-temporal distribution of the two variables. From the graph, it can be seen that when the rainfall is low, groundwater level decreased. From the well location Dhadika, it can be observed that in the recent years from 2009 to 2016, the groundwater level rose upward. In well locations like Ghatal, Ghalkunda, Belsula, Neradeul, Salboni, Brahmajhalur and Badga, groundwater level did not rise up even if the rainfall is high. Such temporal variation will give a preliminary idea of groundwater recharge, whereas it also depends on the land use/ land cover characteristics of the region which should be assessed parallelly. Recently, this part of the West Bengal is facing a decline in rainfall particularly in the early monsoonal month of June and middle monsoonal month of August [26]. Dong et al. [27] also witnessed that a number of climatic model-based studies are suggesting a delayed monsoonal onset in the eastern part of tropical Indian Ocean. For this reason, the summer is getting longer and villagers are more focusing on the extraction of sub-surface water rather than surface water resources. To curb such a situation, rainwater harvesting during the wet spells is urgently required.

\subsection{Impact of land use and land cover change (LULC) on groundwater level}

Land use and land cover controls the groundwater recharge of a region. The utilisation of the soil surface for anthropogenic activities such as settlement and construction of road impedes the surface water infiltration in a region. Conversion of forested land into bare land increases surface run-off and hence decreases recharge. Here, land use and land cover practice around the 20 wells has been analysed for the years 1989, 2000, 2009 and 2018 (Figs. 10, 11, 12 and 13). Classified maps have been prepared using supervised classification. Nine different classes of land use and land cover have been made, and their accuracy assessment has been calculated using Kappa index. The calculated accuracy of 


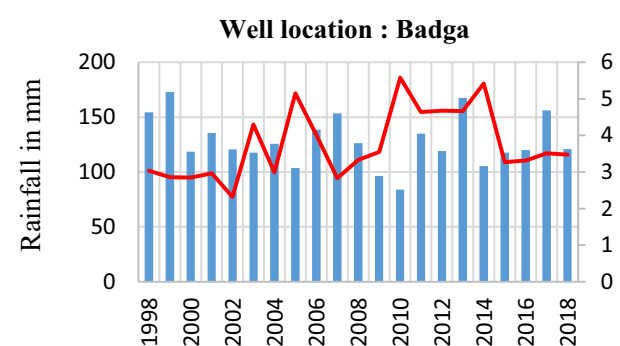

Years

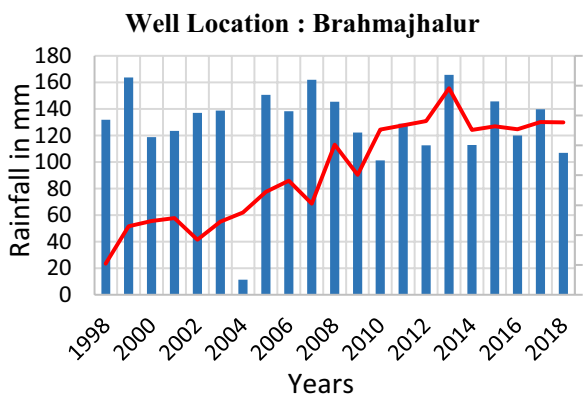

Well Location :Khirpai, Bankura
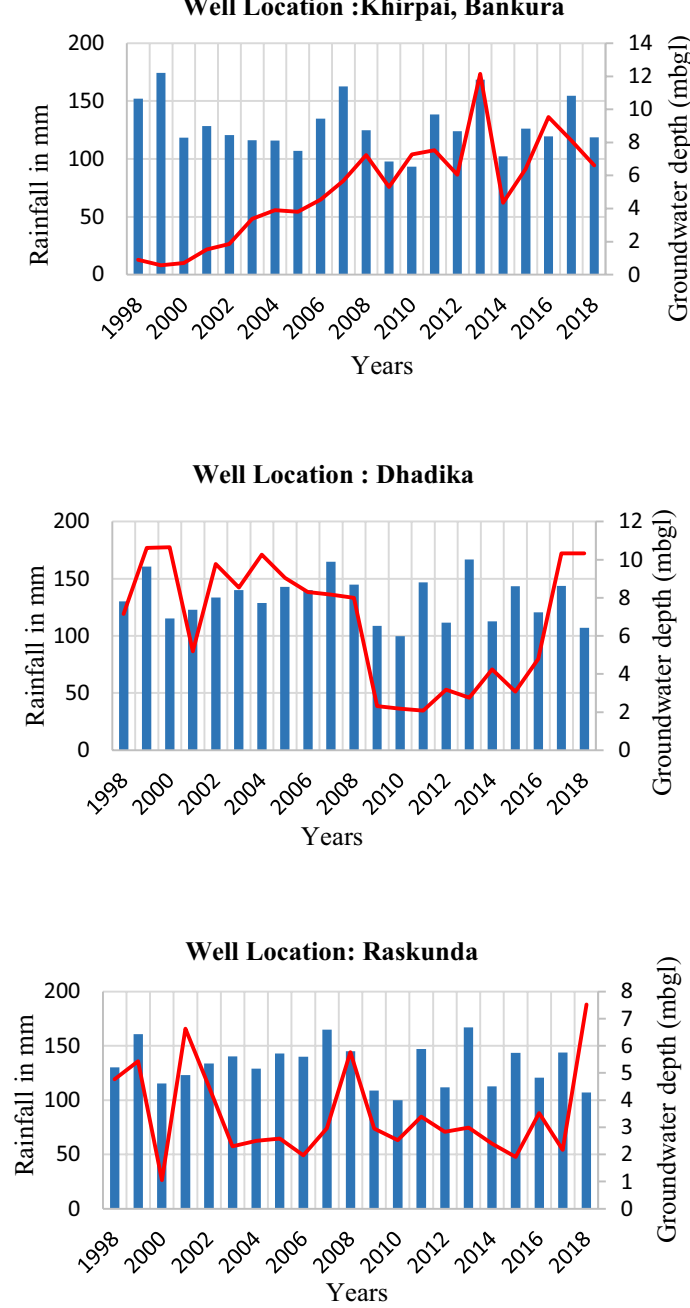

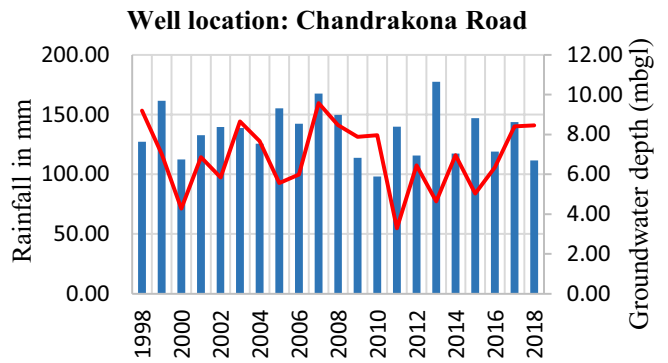

Years
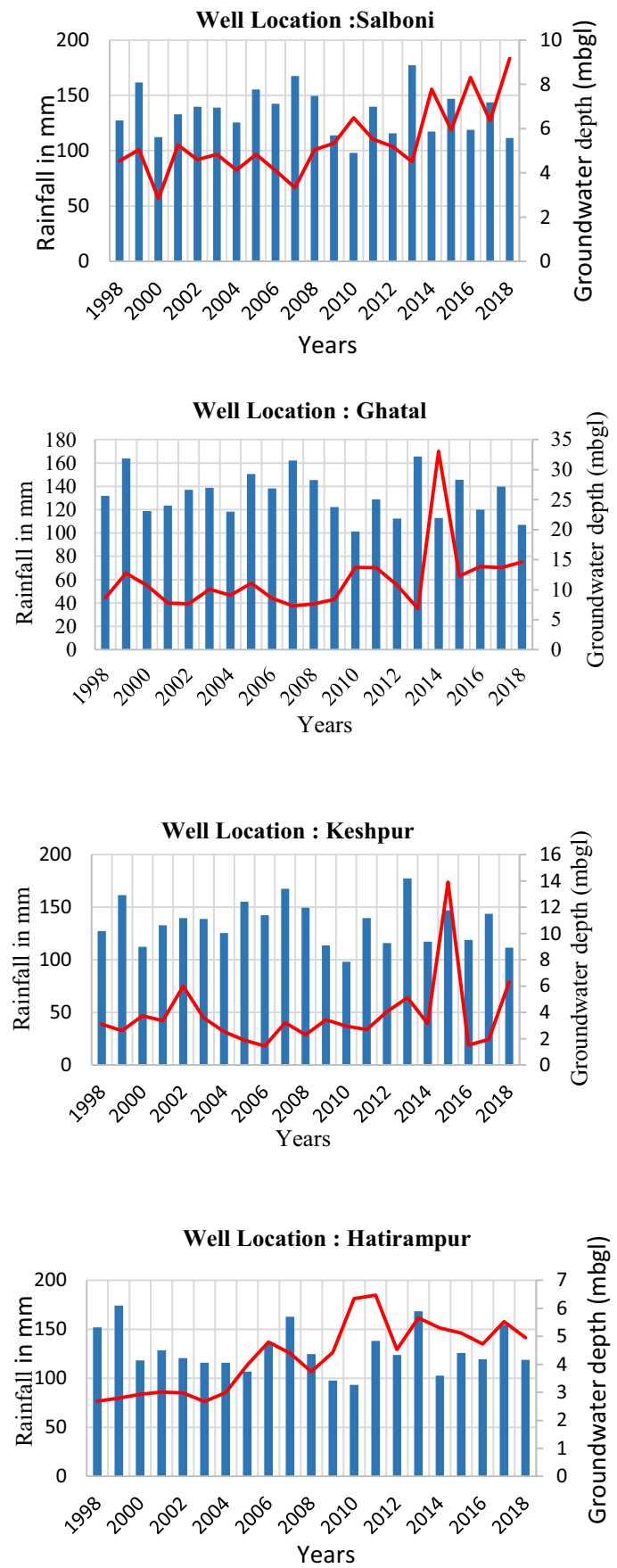

Fig. 9 Graphical representation of average monthly rainfall and groundwater level (1998-2018) 

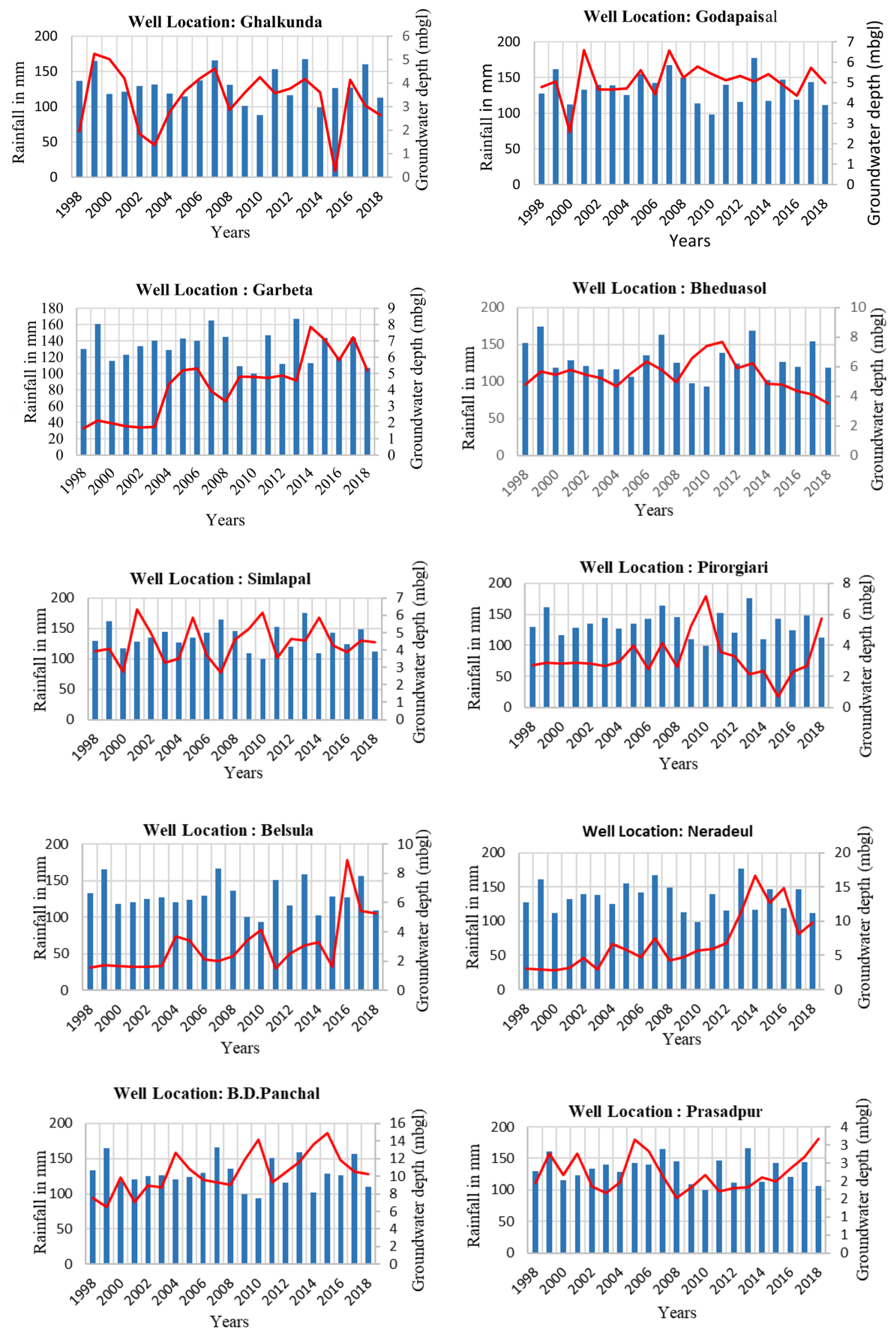

Fig. 9 (continued) 
Fig. 10 Land use and land cover map of 1989

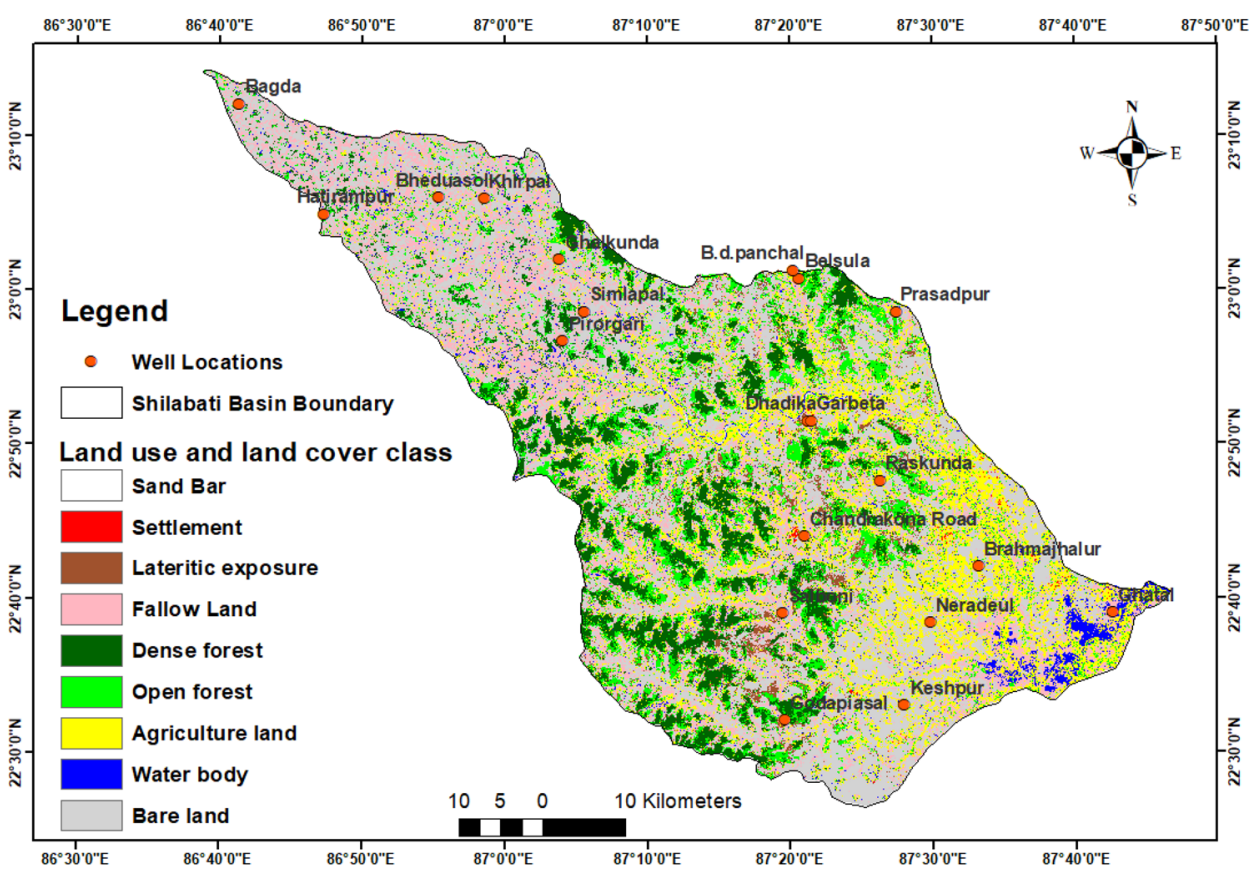

Fig. 11 Land use and land cover map of 2000

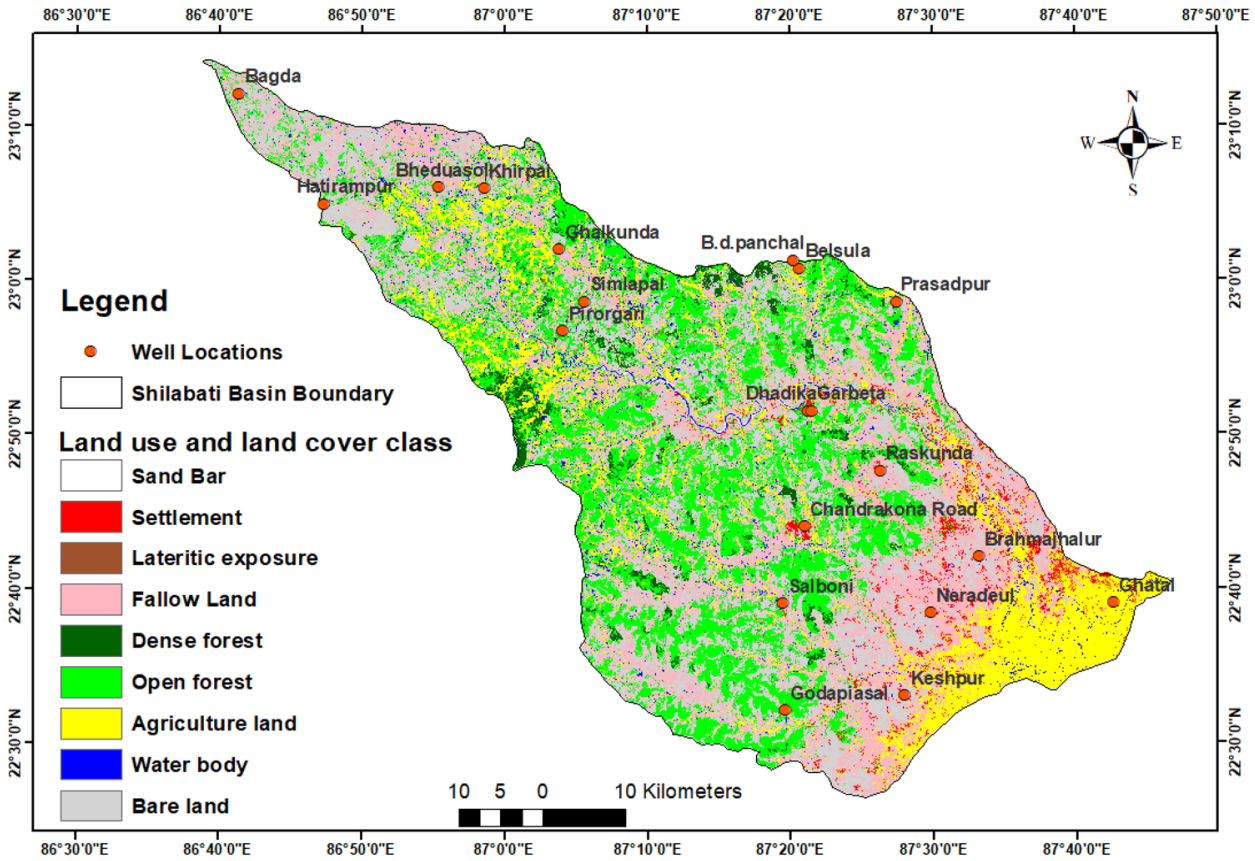

years 1989, 2000, 2009 and 2018 is $94 \%, 96 \%, 97.2 \%$ and $95.2 \%$, respectively. From the analysis of the classified maps, it can be seen that the areas under different LULC classes have been changed over the years (Table 3 ). One of the predominant LULCs in the river basin is bare land which covered $35.24 \%$ in $1989,24.53 \%$ in 2000 , $38.76 \%$ in 2009 and $33.11 \%$ in 2018 among all the other classes. The presence of bare land can be found scattered throughout the regions which indicates poor groundwater recharge, higher peaks of surface run-off and soil erosion that is quite predominant over the basin. Soil erosion also discourages groundwater recharge for this suitable cropping pattern, and crop rotation technique should be adopted for its sustainable management [28]. Percentage of dense forest cover over the region has also decreased from 1989 , i.e. from $10.88 \%$ of the total area to $4.93 \%$ in 2018 . This decrease in natural vegetation has far reaching effect on the groundwater 
Fig. 12 Land use and land cover map of 2009
Fig. 13 Land use and land cover map of 2018
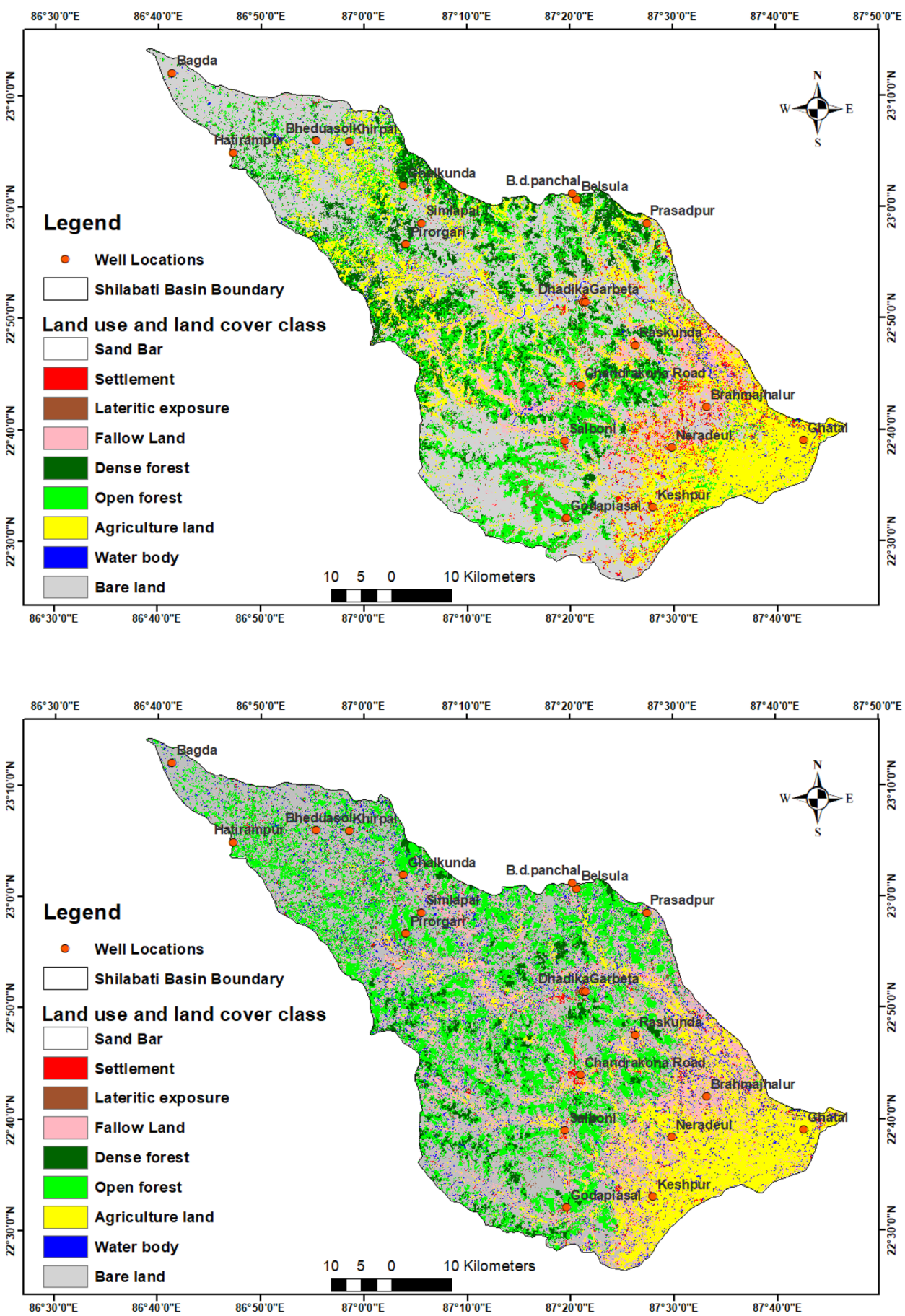

potential of the study area. But the percentage of water bodies (like ponds) increased over the study area maybe to irrigate the agricultural land as the rainfall amount decreased. A locational description of the (Table 4) wells has also been done based on the LULC of the four years to identify the LULC class in and around the wells controlling the recharge pattern. Well location at Chandrakona road, Keshpur and Neradual which has been surrounded by agricultural land and fallow land in 1989 changed to settlement in 2018 which implies poor infiltration scenario of the basin. From the census report of 2011 [29], it can also be found that Chandrakona has developed into a town as such concretion increased and groundwater level decreased due to poor recharge. The majority of the well locations have been transformed into bare land where sustainable management, afforestation and artificial recharge are needed to increase the stock of sub-surface water resources. 
Table 3 Areal description of LULC class

\begin{tabular}{|c|c|c|c|c|c|c|c|c|}
\hline \multirow[t]{2}{*}{ Class } & \multicolumn{2}{|l|}{1989} & \multicolumn{2}{|l|}{2000} & \multicolumn{2}{|l|}{2009} & \multicolumn{2}{|l|}{2018} \\
\hline & Area in $\mathrm{km}^{2}$ & $\begin{array}{l}\text { Area in per- } \\
\text { centage }\end{array}$ & Area in $\mathrm{km}^{2}$ & $\begin{array}{l}\text { Area in per- } \\
\text { centage }\end{array}$ & Area in $\mathrm{km}^{2}$ & $\begin{array}{l}\text { Area in per- } \\
\text { centage }\end{array}$ & Area in $\mathrm{km}^{2}$ & $\begin{array}{l}\text { Area in } \\
\text { percent- } \\
\text { age }\end{array}$ \\
\hline Agriculture land & 649.61 & 16.71 & 598.11 & 15.41 & 829.92 & 9.86 & 577.16 & 14.87 \\
\hline Dense forest & 422.96 & 10.89 & 84.65 & 2.18 & 382.79 & 38.76 & 191.36 & 4.93 \\
\hline Bare land & 1369.25 & 35.24 & 951.87 & 24.53 & 1504.41 & 0.97 & 1285.18 & 33.11 \\
\hline Lateritic exposure & 100.18 & 2.58 & 12.28 & 0.32 & 37.65 & 16.36 & 45.33 & 1.17 \\
\hline Open forest & 431.89 & 11.12 & 1057.55 & 27.25 & 635.02 & 16.36 & 944.51 & 24.34 \\
\hline Sand bar & 1.19 & 0.031 & 2.54 & 0.065 & 5.40 & 0.14 & 0.74 & 0.019 \\
\hline Settlement & 3.55 & 0.091 & 72.29 & 1.86 & 102.67 & 2.65 & 63.15 & 1.63 \\
\hline Water body & 91.04 & 2.34 & 79.38 & 2.05 & 72.93 & 1.88 & 173.69 & 4.48 \\
\hline Fallow & 816.00 & 21 & 1022.17 & 26.34 & 310.28 & 7.99 & 599.93 & 15.46 \\
\hline
\end{tabular}

Table 4 Locational description of wells based on LULC change from 1989 to 2018

\begin{tabular}{lllll}
\hline Well location & 1989 & 2000 & 2009 & 2018 \\
\hline Badga & Bare land & Bare land & Bare land & Bare land \\
Chandrakona road & Agricultural land & Settlement & Fallow land & Settlement \\
Brahmajhalur & Bare land & Bare land & Fallow land & Fallow land \\
Dhadika & Lateritic exposure & Open forest & Open forest & Bare land \\
Salboni & Bare land & Open forest & Fallow land & Fallow land \\
Godapaisal & Fallow land & Fallow land & Fallow land & Agricultural Land \\
Keshpur & Fallow land & Fallow land & Settlement & Settlement \\
Neradual & Fallow land & Settlement & Settlement & Settlement \\
Raskunda & Bare land & Fallow land & Fallow land & Agricultural land \\
Belsula & Open forest & Open forest & Open forest & Bare land \\
B.D. Panchal & Fallow land & Agricultural land & Agricultural land & Fallow land \\
Pirorgari & Dense forest & Fallow land & Bare land & Open forest \\
Prasadpur & Agricultural land & Open forest & Bare land & Open forest \\
Simlapal & Bare land & Bare land & Bare land & Bare land \\
Khirpai & Bare land & Fallow land & Bare land & Bare land \\
Hatirampur & Dense forest & Bare land & Open forest & Bare land \\
Bheduasol & Bare land & Open forest & Bare land & Dense forest \\
Ghalkunda & Bare land & Open forest & Dense forest & Dense forest \\
Garbeta & Agricultural Land & Agricultural land & Agricultural land & Fallow land \\
Ghatal & Fallow land & Agricultural land & Agricultural land & Agricultural land \\
\hline
\end{tabular}

\subsection{Spatio-temporal distribution of groundwater level since 1996}

To determine the spatio-temporal distribution of groundwater level of each of the wells, data from 1996 to 2018 have been downloaded for three seasons pre-monsoon, monsoon and post-monsoon to calculate the descriptive statistics such as mean, standard deviation, skewness, kurtosis, variance, median, quartile 1, quartile 2 , quartile 3 and their inter-quartile range which are discussed in Tables S1,
S2 and S3 (Online Resource 1). From the computed Table S1 (Online Resource 1), it can be found that the mean water level of 22 years at pre-monsoon in Chandrakona and B.D. Panchal is $11.813 \mathrm{mbgl}$ (metre below groundwater level) and $12.733 \mathrm{mbgl}$, respectively, which is quite low. Huge extraction of groundwater for agricultural activities and other domestic purpose may be the prime reason of concern. Standard deviation of the pre-monsoon water level depth is also high where high value is witnessed at Neradual which is $6.405 \mathrm{mbgl}$. During the monsoon, the 
mean groundwater level slightly improved which ranges between 2 and $7 \mathrm{mbgl}$ that is mainly due to the effect of recharge through precipitation. During the post-monsoon season, the mean ranges from 1.56 to $8.6 \mathrm{mbgl}$ which also reflects the replenishment of aquifers through infiltration. Most of the values of the pre-monsoon, monsoon and post-monsoon are highly skewed and showing asymmetrical distribution. Five wells of pre-monsoon, five wells of monsoon and four wells of post-monsoon are showing highly skewed values. Inter-quartile range denotes the measure of variability. The inter-quartile range is higher in case of well location at Dhadika, B.D Panchal and Ghatal for monsoon season, Dhadika, Neradeul and Ghatal for pre-monsoon and B.D Panchal and Khirpai for postmonsoon. The computed table will help to understand the variability of the groundwater level. Spatio-temporal distribution of the groundwater level of the three seasons is shown in Figs. 14, 15, 16, 17 and 18. From the distribution, it can be seen that the mid-section of the basin is having lower groundwater level during the post-monsoon season where the development of the settlement can be observed. In other words, most of the depth of the groundwater level is lowered after the offset of the monsoonal season. As the volume of precipitation in the monsoonal months decreased, farmers are utilising groundwater for paddy and vegetable cultivation affecting the sub-surface
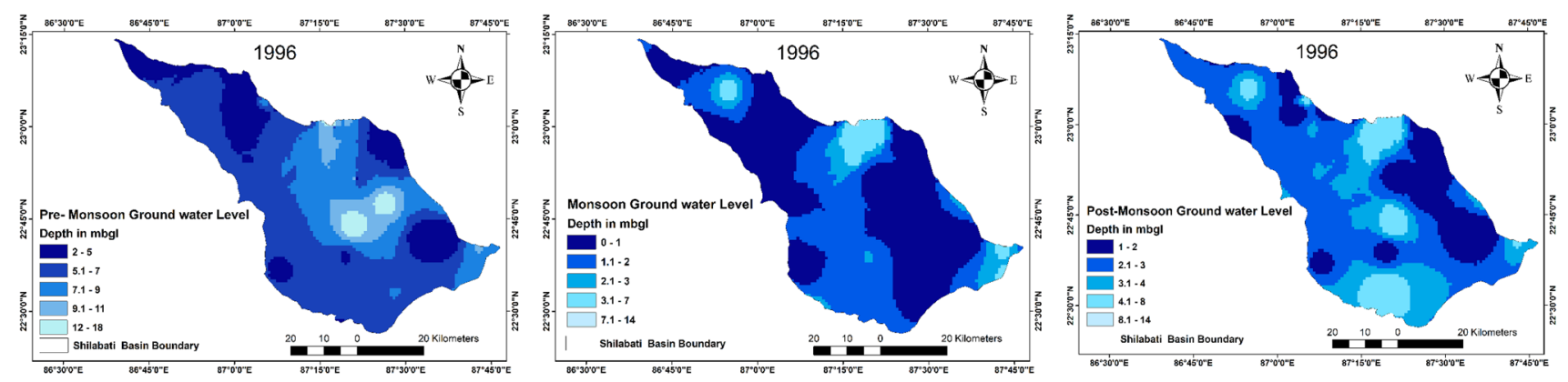

Fig. 14 Groundwater level at pre-monsoon, monsoon and post-monsoon 1996
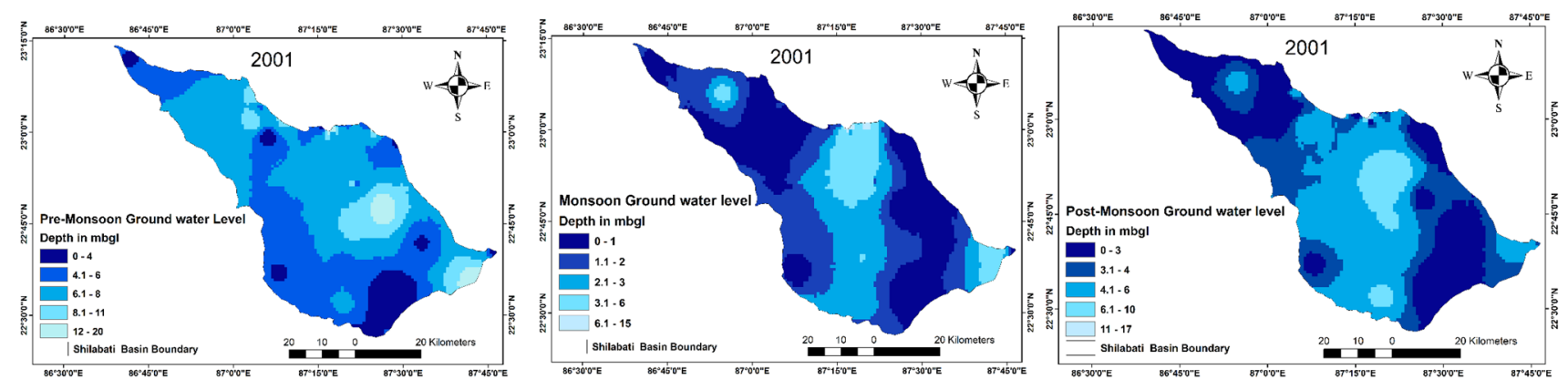

Fig. 15 Groundwater level at pre-monsoon, monsoon and post-monsoon 2001
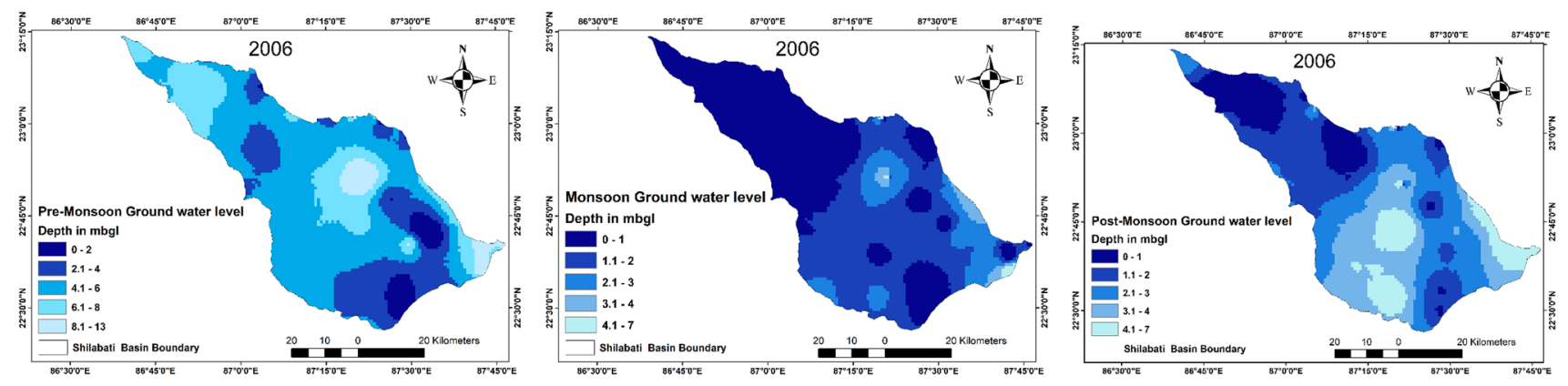

Fig. 16 Groundwater level at pre-monsoon, monsoon and post-monsoon 2006 

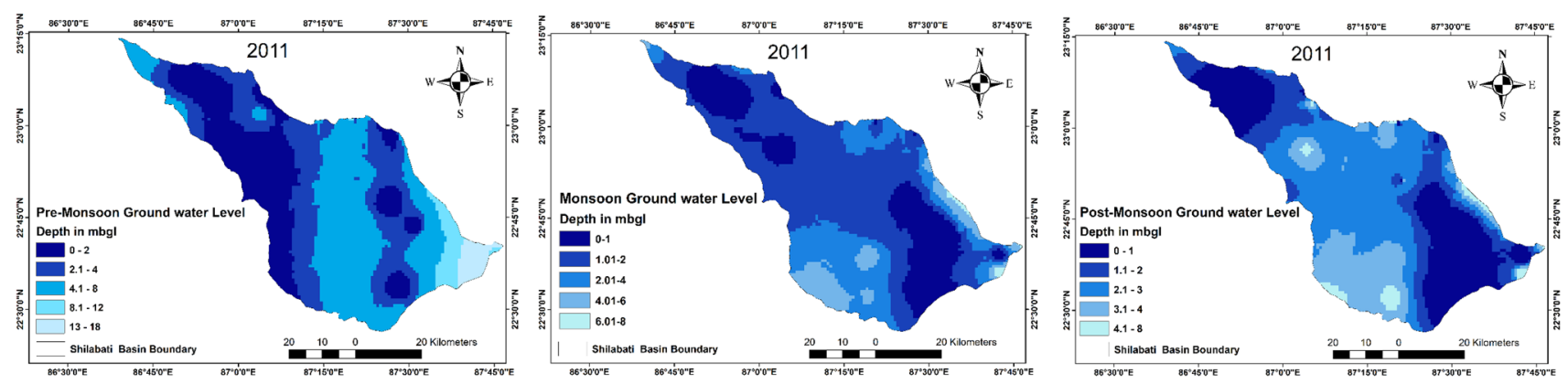

Fig. 17 Groundwater level at pre-monsoon, monsoon and post-monsoon 2011
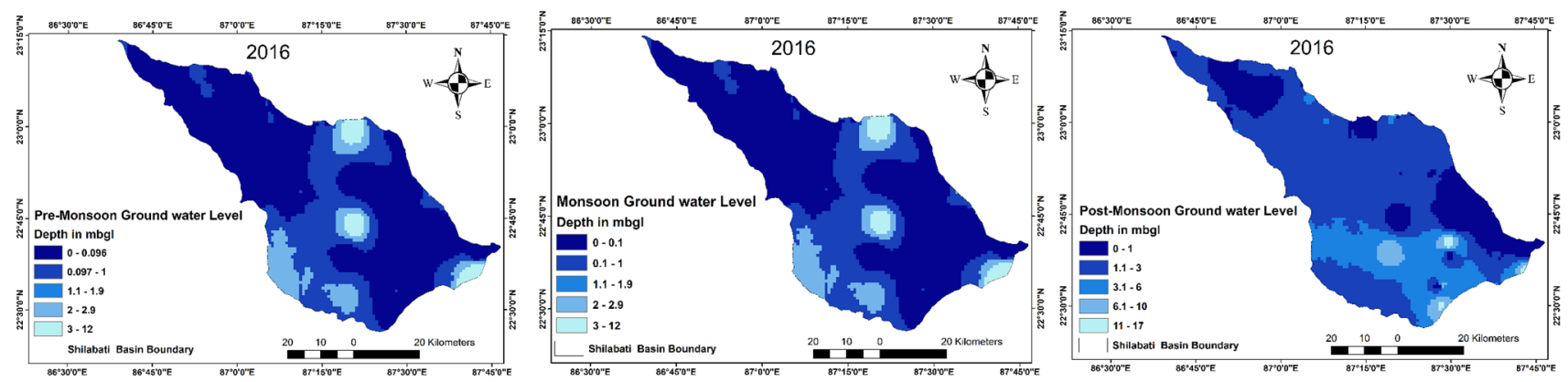

Fig. 18 Groundwater level at pre-monsoon, monsoon and post-monsoon 2016

water stock of drier periods. From the socio-economic survey conducted by the authors also revealed the increased use of submersible pumping system in the recent days due to the poor and irregular water supply from the canals, drying up of the river beds and most of dug wells has become obsolete. More than 50-70 such pumps operate in the villages falling within the basin for agriculture and domestic purposes. On a global scale, this kind of spatiotemporal change analysis is fewer in number because of the lack of groundwater monitoring systems [30] but is needed for sustainable river basin management.

\subsection{Groundwater level trend analysis}

The asymmetrical distribution as observed from the statistical analysis substantiates the need for the application of the nonparametric trend method to identify the trends in the data sets. The time series data from 1996 to 2018 for the pre-monsoon, monsoon and postmonsoon have been taken under the study. The seasonal variability and groundwater crisis are observed in the study area, which can be due to the following (a) influence of the uneven distribution of precipitation and its deficit in the recent years, (b) conversion of bare land, (c) heavy extraction of groundwater through submersible pumping system for agricultural activities and domestic purpose, (d) extensive sand mining in the river bed hampering the conjunctive system between groundwater and surface water resources. From the field studies, extensive sand mining in various sections of the river has been observed disturbing the interaction of the two most important hydrological systems (Fig. S1 Online Resource 2). At the best of our knowledge, no reference studies have been done till date within the basin using the groundwater level data, whereas reference studies are available related to the soil erosion. Mann-Kendall test statistics have been applied in this paper to witness the trend. In this method, each monitoring well visualises the groundwater dynamics of the adjoining areas and each trend gives an idea of the extent of the fluctuation over the period of time [31]. The method has been executed using XLSTAT software. The trend has been analysed at a significance level of 0.05 or $5 \%$ of confidence level. Two hypotheses have been considered: $H_{0}$ (null hypothesis) denotes the absence of trend and $H_{A}$ denotes the presence of trend within the data set. To understand the magnitude and intensity of the trend, Sen's slope estimate has also been calculated. The Kendall's tau, S, VAR, $P$ and slope of each of the wells of three seasons have been given in a tabular format (Table 5). Under pre-monsoon condition, out of the 20 wells, nine wells are showing an increasing trend which means the groundwater level is declining at a higher rate. Higher value of groundwater level indicates greater decline 
Table 5 Results of MannKendall test statistics

\begin{tabular}{|c|c|c|c|c|c|c|}
\hline Well location & Kendall tau & $\mathrm{S}$ & VAR & $P$ & Slope & Trend \\
\hline \multicolumn{7}{|l|}{ Pre-monsoon } \\
\hline Badga & 0.198 & 50 & 1432.67 & 0.195 & 0.061 & No \\
\hline Chandrakona road & -0.079 & -20 & 1432.37 & 0.616 & -0.087 & No \\
\hline Brahmajhalur & -0.721 & 182.00 & 1432.67 & $<0.0001$ & 0.322 & Increasing \\
\hline Dhadika & -0.210 & -53 & 1431.67 & 0.19 & -0.222 & No \\
\hline Salboni & 0.467 & 118 & 1432.67 & 0.002 & -0.165 & Increasing \\
\hline Godapaisal & -0.325 & -82 & 1432.67 & 0.032 & -0.039 & Decreasing \\
\hline Keshpur & -0.341 & -86 & 1432.67 & 0.025 & -0.169 & Decreasing \\
\hline Neradeul & 0.459 & 116 & 1432.67 & 0.002 & 0.609 & Increasing \\
\hline Raskunda & -0.238 & -60 & 1432.37 & 0.119 & -0.114 & No \\
\hline Belsula & 0.214 & 54 & 1432.67 & 0.161 & 0.039 & No \\
\hline B.D. Panchal & 0.726 & 183 & 1431.67 & $<0.0001$ & 0.425 & Increasing \\
\hline Pirorgari & 0.293 & 74 & 1432.67 & 0.054 & 0.081 & Increasing \\
\hline Prasadpur & -0.143 & -36 & 1432.67 & 0.05 & -0.037 & No \\
\hline Simlapal & -0.178 & -45 & 1432.67 & 0.245 & -0.061 & No \\
\hline Khirpai & 0.290 & 73 & 1432.37 & 0.057 & 0.26 & Increasing \\
\hline Hatirampur & 0.663 & 167 & 1432.67 & $<0.0001$ & 0.215 & Increasing \\
\hline Bheduasol & -0.139 & -35 & 1431.67 & 0.369 & -0.023 & No \\
\hline Ghalkunda & -0.087 & -22 & 1432.67 & 0.579 & 0.579 & No \\
\hline Garbeta & 0.420 & 106 & 1432.67 & 0.289 & 0.289 & Increasing \\
\hline Ghatal & 0.412 & 104 & 1432.67 & 0.404 & 0.404 & Increasing \\
\hline \multicolumn{7}{|l|}{ Monsoon } \\
\hline Badga & -0.020 & -5.0 & 1433.67 & 0.916 & -0.002 & No \\
\hline Chandrakona road & 0.225 & 57 & 1433.67 & 0.139 & 0.073 & No \\
\hline Brahmajhalur & 0.433 & 109 & 1431.67 & 0.004 & 0.046 & Increasing \\
\hline Dhadika & -0.158 & -40 & 1432.67 & 0.303 & -0.224 & No \\
\hline Salboni & 0.502 & 127 & 1433.67 & 0.001 & 0.119 & Increasing \\
\hline Godapaisal & 0.135 & 34 & 1432.67 & 0.383 & 0.020 & No \\
\hline Keshpur & 0.289 & 73 & 1433.67 & 0.057 & 0.031 & No \\
\hline Neradeul & -0.143 & -36 & 1432.67 & 0.355 & -0.033 & No \\
\hline Raskunda & 0.176 & 44 & 1428 & 0.255 & 0.024 & No \\
\hline Belsula & 0.320 & 81 & 1433.67 & 0.035 & 0.030 & Increasing \\
\hline B.D. Panchal & -0.099 & -25 & 1433.67 & 0.526 & -0.172 & No \\
\hline Pirorgari & -0.182 & -46 & 1432.67 & 0.234 & -0.006 & No \\
\hline Prasadpur & -0.147 & -37 & 1431.67 & 0.341 & -0.018 & No \\
\hline Simlapal & -0.115 & -29 & 1433.67 & 0.460 & -0.024 & No \\
\hline Khirpai & 0.826 & 209 & 1433.67 & $<0.0001$ & 0.395 & Increasing \\
\hline Hatirampur & -0.028 & -7.6 & 1431.67 & 0.874 & -0.005 & No \\
\hline Bheduasol & -0.115 & -29 & 1433.66 & 0.460 & -0.100 & No \\
\hline Ghalkunda & 0.166 & 42 & 1432.67 & 0.279 & 0.031 & No \\
\hline Garbeta & 0.375 & 95 & 1433.67 & 0.013 & 0.049 & Increasing \\
\hline Ghatal & 0.217 & 55 & 1433.67 & 0.154 & 0.257 & No \\
\hline \multicolumn{7}{|l|}{ Post-monsoon } \\
\hline Badga & 0.512 & 129 & 1431.67 & 0.001 & 0.086 & Increasing \\
\hline Chandrakona road & -0.036 & -9.00 & 1433.67 & 0.833 & -0.036 & No \\
\hline Brahmajhalur & 0.510 & 129 & 1433.67 & 0.001 & 0.261 & Increasing \\
\hline Dhadika & -0.383 & -97 & 1433.67 & 0.011 & -0.244 & Decreasing \\
\hline Salboni & 0.628 & 159 & 1433.67 & $<0.0001$ & 0.176 & Increasing \\
\hline Godapaisal & 0.067 & 17 & 1433.67 & 0.673 & 0.045 & No \\
\hline Keshpur & 0.143 & 36 & 1432.67 & 0.355 & 0.046 & No \\
\hline Neradeul & 0.562 & 142 & 1432.67 & 0.001 & 0.486 & Increasing \\
\hline
\end{tabular}


Table 5 (continued)

\begin{tabular}{lllllll}
\hline Well location & Kendall tau & $\mathrm{S}$ & VAR & $\mathrm{P}$ & Slope & Trend \\
\hline Raskunda & 0.127 & 32 & 1432.67 & 0.413 & 0.033 & No \\
Belsula & 0.436 & 110 & 1432.67 & 0.004 & 0.060 & Increasing \\
B.D. Panchal & 0.499 & 126 & 1432.67 & 0.001 & 0.384 & Increasing \\
Pirorgari & 0.293 & 74 & 1432.67 & 0.054 & 0.081 & Increasing \\
Prasadpur & 0.350 & 88 & 1430.67 & 0.021 & 0.068 & Increasing \\
Simlapal & 0.218 & 55 & 1431.67 & 0.154 & 0.110 & No \\
Khirpai & 0.689 & 174 & 1432.67 & $<0.0001$ & 0.309 & Increasing \\
Hatirampur & 0.737 & 186 & 1432.67 & $<0.0001$ & 0.251 & Increasing \\
Bheduasol & 0.234 & 59 & 1431.67 & 0.125 & 0.035 & No \\
Ghalkunda & 0.345 & 87 & 1431.67 & 0.023 & 0.134 & Increasing \\
Garbeta & 0.483 & 122 & 1432.67 & 0.001 & 0.292 & Increasing \\
Ghatal & 0.269 & 68 & 1432.67 & 0.077 & 0.144 & No \\
\hline
\end{tabular}

as the level is calculated or measured from surface as zero. During the monsoon, five wells, namely Brahmajhalur, Salboni, Simlapal, Belsula and Garbeta, are showing increasing trend, i.e. groundwater level is declining and others showed no significant trend. In post-monsoon season, increasing trend is observable in 12 wells and one well (Dhadika) is showing a decreasing trend. Groundwater level in post-monsoon period is important as it signifies the quantity of recharge after monsoonal precipitation. Most of the wells showing upward trend are located near the agricultural land as reflected from the LULC analysis where extensive extraction is going on. A field survey is also conducted to inspect the groundwater crisis where most of the inhabitants informed about the extensive withdrawal using higher energy utilisation and at the higher cost. In the summer months, villagers experience drought-like condition particularly in the upstream and the middle section because of poor rainfall and practice single crop cultivation using subsurface water reducing the sustainability of aquifers. One of the major problems of the study area includes overabstraction from the aquifers and river and increasing demand of the water by the growing population. Under such situation, this paper contributes in identifying the hotspot areas in terms of water level decline that will help to undertake watershed management techniques likewise.

\subsection{Cluster analysis of wells based on their fluctuation scenario}

Agglomerated hierarchical cluster (AHC) has been applied to classify the wells according to their fluctuation variability. It is an important statistical tool that determines each case into a separate group or cluster and connects each cluster until one cluster remains [32]. Here, hierarchical clustering based on the Ward's linkage method has been applied. Fluctuation of the groundwater has been calculated subtracting the pre-monsoon from post-monsoon groundwater level for the period of 22 years. This statistical tool has been applied to observe long-term variability of fluctuation of groundwater level in wells and grouping them which are showing similar trends for sustainable management. Groundwater fluctuation helps in understanding the vulnerability of aquifers in terms of recharge potential controlled by climatological and anthropogenic factors The wells have been grouped into four clusters, and the details of the analysis generated from the software have been given in tabular format (Table 6). The dendrogram (Fig. 19) shows the cluster hierarchy of the wells located in the study area. It has been observed from the spatio-temporal variation in the wells of different clusters (Fig. 20) that 15 wells showed similar fluctuation

Table 6 Details of the cluster analysis as executed from XLSTAT software

\begin{tabular}{|c|c|c|c|c|}
\hline Class & Cluster 1 & Cluster 2 & Cluster 3 & Cluster 4 \\
\hline Objects & 15 & 1 & 2 & 2 \\
\hline Sum of weights & 15 & 1 & 2 & 2 \\
\hline Within-class variance & 113.076 & 0.000 & 189.891 & 140.186 \\
\hline $\begin{array}{l}\text { Minimum distance to } \\
\text { centroid }\end{array}$ & 6.173 & 0.000 & 9.744 & 8.372 \\
\hline $\begin{array}{l}\text { Average distance to } \\
\text { centroid }\end{array}$ & 9.772 & 0.000 & 9.744 & 8.372 \\
\hline $\begin{array}{l}\text { Maximum distance to } \\
\text { centroid }\end{array}$ & 16.271 & 0.000 & 9.744 & 8.372 \\
\hline
\end{tabular}




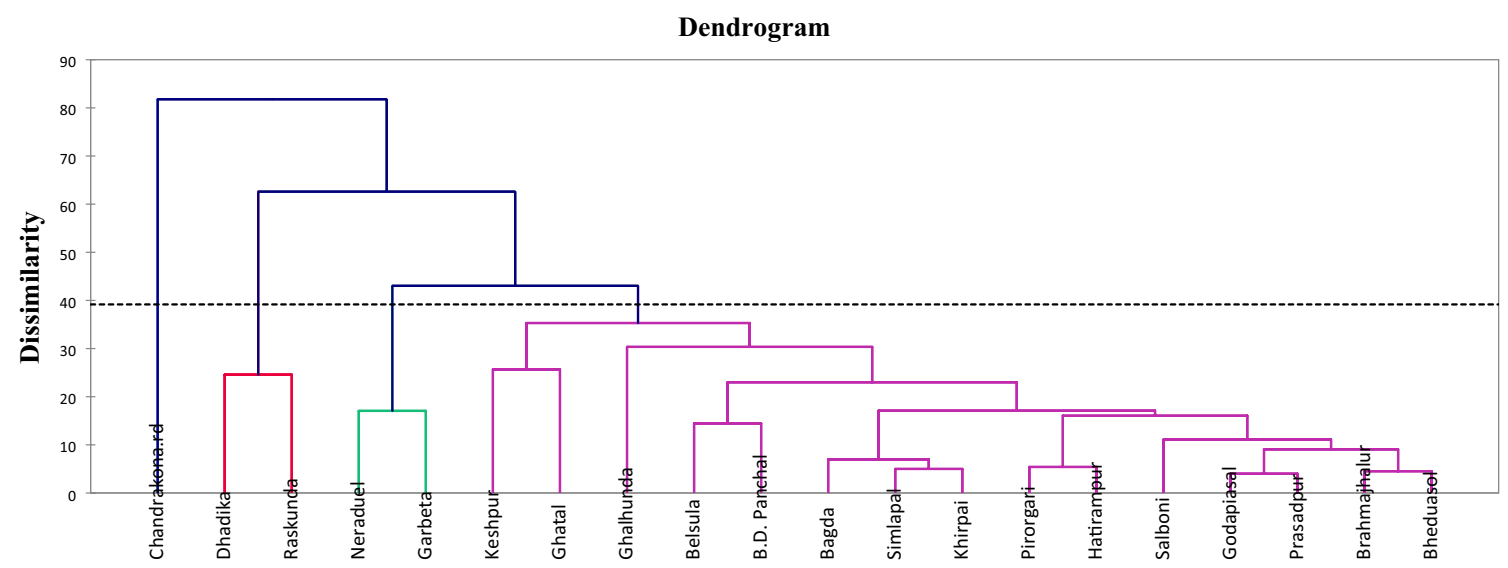

Fig. 19 Dendrogram of the clusters

Fig. 20 Map showing four clusters of well

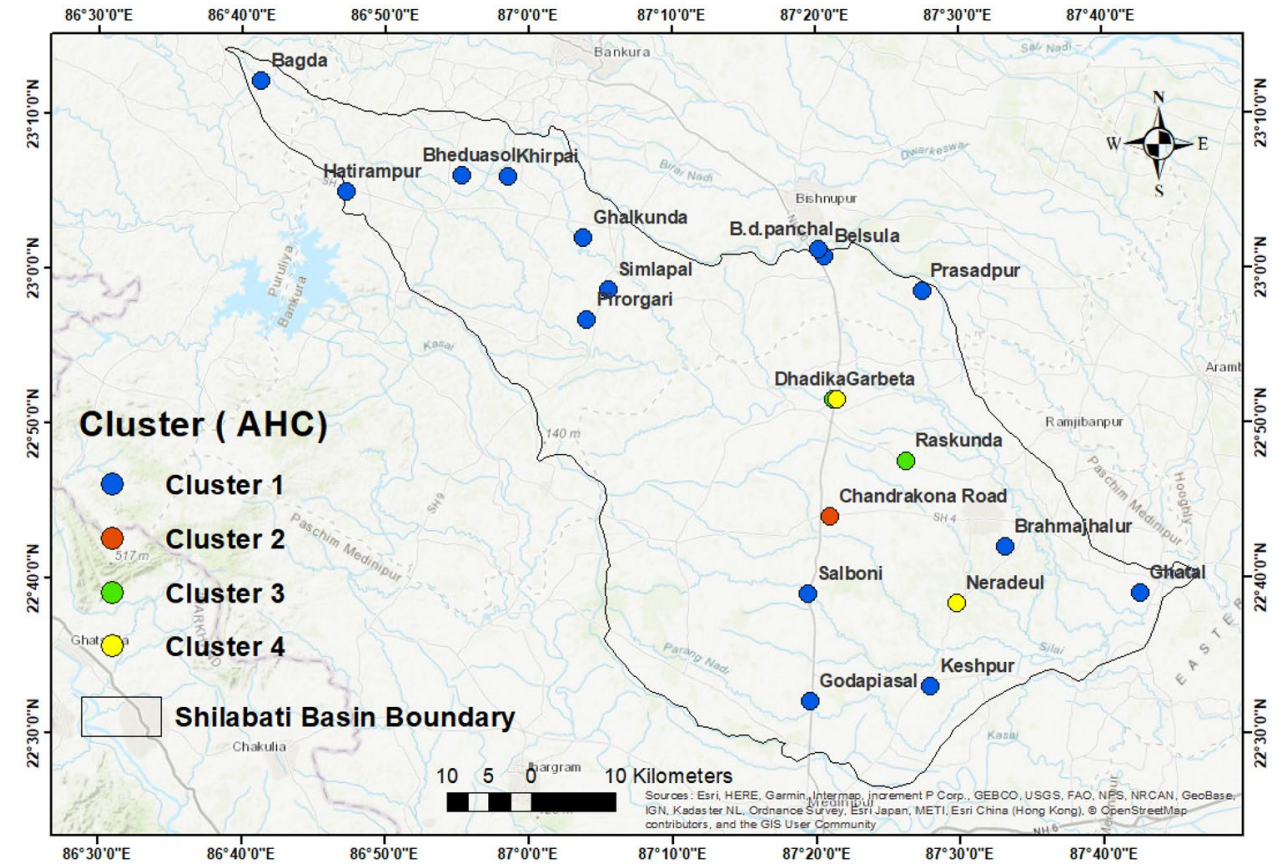

Box and Whisker Plot of Groundwater Fluctuation

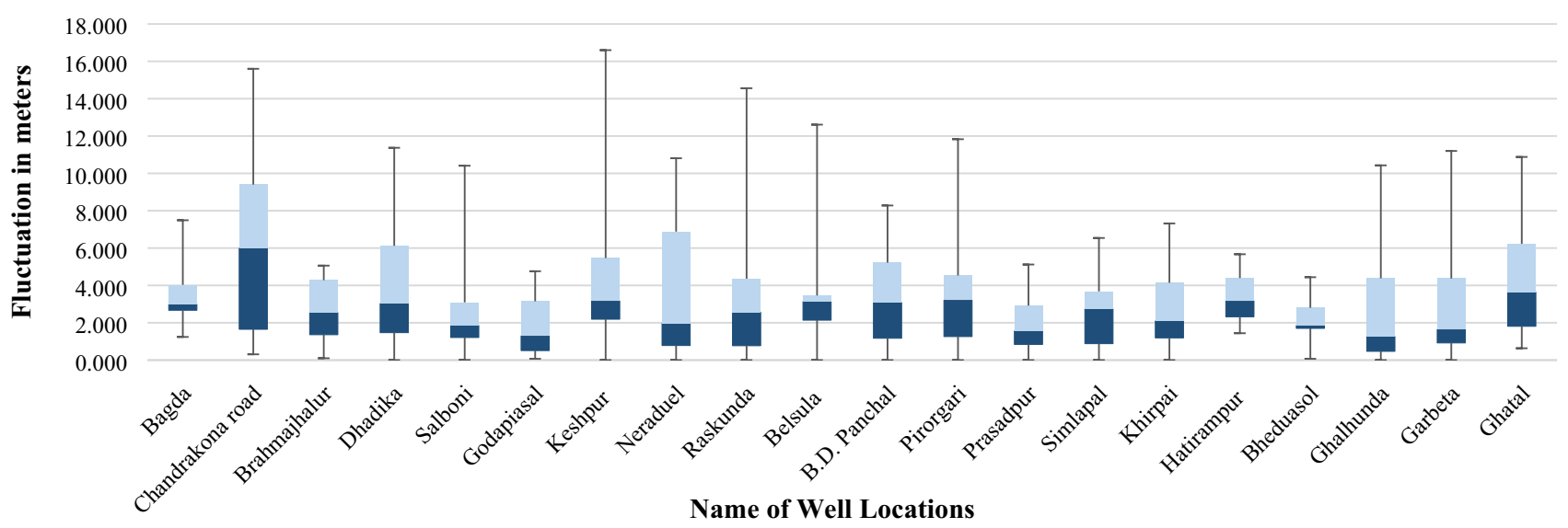

Fig. 21 Box-and-whisker plot of the fluctuation variation in well points 
variation are in cluster 1 where the mean fluctuation ranged between 1.8 and $4.329 \mathrm{~m}$. The second cluster consists of only one well whose mean fluctuation is $6.305 \mathrm{~m}$, and the third cluster and fourth cluster consist of two wells each with mean fluctuation between $4.52-4.01 \mathrm{~m}$ and 3.46-2.861, respectively. The fluctuation is higher in clusters 2 and 3 . Cluster 3 consists of well location of Chandrakona road, and mean fluctuation is about $6.305 \mathrm{~m}$. The box-and-whisker plot (Fig. 21) gives the indication of fluctuation of each of the wells with their respective variability. The reason for the higher fluctuation at well location Chandrakona road can be due to change in land use and land cover which was mainly surrounded by agricultural land in 1986 and transformed into a built-up area in 2018. Thus, concretion has changed the recharge scenario. Another reason for the increased fluctuation witnessed in the wells is mainly due to the precipitation variability and time taken by the aquifer to replenish as groundwater extraction overdrafts the recharge. According to CGWB published report of West Bengal (2015-2016) [33], $28.30 \%$ of the wells in Bankura district, $38.9 \%$ of the wells in Puruliya district and $38.6 \%$ of the wells in West Medinapore district are having a water table depth of 5-10 m in the month of November. A part of all the three districts falls under the basin area. Such type of cluster analysis is also new in this river basin. Towards efficient planning for sustainable groundwater management, grouping of the wells will help in the adoption of cluster-wise management strategies [34].

\subsection{Identification of groundwater drought years using Standard Groundwater Level Index}

One of the natural disasters that result in the loss of life and economic destruction is drought [35]. Nowadays, groundwater crisis has become a global problem. Drought respective of groundwater is a need of concern as it is one of the freshwater reserve and an important source of drinking source for people. Due to climate change, a deficit in precipitation can be reflected in water crisis particularly in groundwater. Analysis of the hydro-geological drought using groundwater level data helps in stabilising all the ecosystem services [36]. Here, groundwater drought has been analysed using Standard Groundwater Level Index (SGWI). SGWI has been calculated for years 1996-2018 of each of the wells for three seasons. It is not possible or feasible to graphically represent the calculated data of each to present SGWI within the manuscript. The identified drought and non-drought year has been given in tabular format (Table 7). In pre-monsoon periods, well locations like Dhadika, Godapaisal, Keshpur, Chandrakona have more drought years, and in monsoon, well locations like Prasadpur, Simlapal, Raskunda have greater drought years, whereas in post-monsoon, Simlapal, Bheduasol, Neradeul have a higher frequency of drought years. The identification of drought years along with the trend analysis will help in micro-watershed conservation served by the water source locations. In 2018 (Fig. 22), the wells located in the lower middle section faced groundwater drought in terms of lowering of the water level. This section of the basin experiences high temperature variations and uneven distribution of rainfall all-round the year. According to Ghosh [37], the chances of extreme drought attack are more prone to the western degraded plateaus comprising parts of Puruliya, Bankura and West Medinapore districts of West Bengal and some parts of Rarh Bengal. Beside the climate anomalies, these wells are mainly located near the settlement centre (Fig. 13) where the current anthropogenic activities are leading to the poor recharge. In a region of rapid urbanisation and scarce surface water, detailed investigation of the effects of land use and land cover on groundwater recharge is needed [38]. Fewer studies have been conducted on the regional as well as global characterisation of the groundwater drought and its regular monitoring [4], and it is also new to this study area.

\section{Conclusion}

The present study provided the results of the groundwater vulnerability in a river basin of West Bengal, India, in the context of climate change and extensive anthropogenic activities. The basin is dominated by agricultural practise, but in the recent years, production has been decreasing because of a deficit in precipitation and decline in the groundwater level. The study has been conducted in Shilabati river basin of West Bengal, India, located at the extension of Chotonagpur Plateau. A number of statistical techniques like descriptive test statistics, Mann-Kendall trend test, cluster analysis and SGWI have been applied to highlight the scenario. The land use and land cover analysis made here showed a decrease in dense forest cover from $10.88 \%$ in 1989 to $4.93 \%$ in 2018 . Such decrease in the forest cover increases bare land and reduces the water 


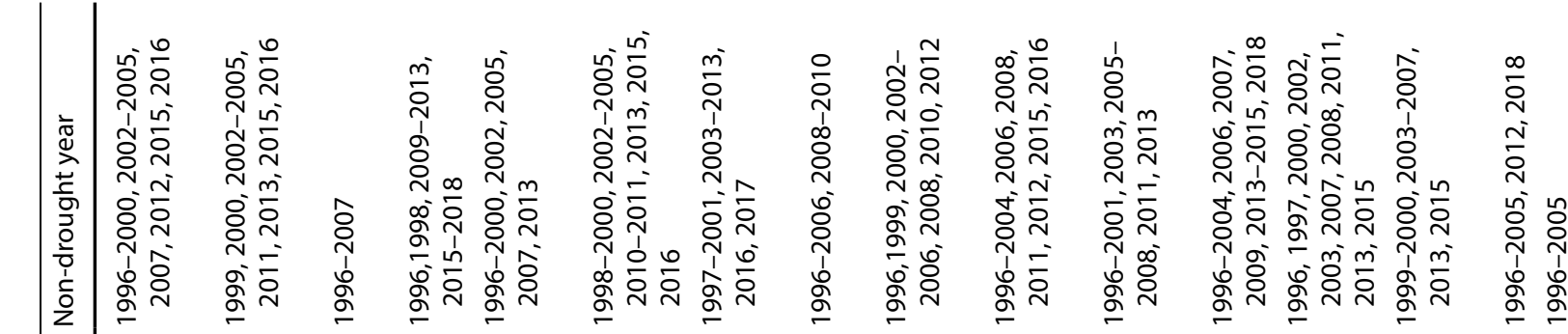

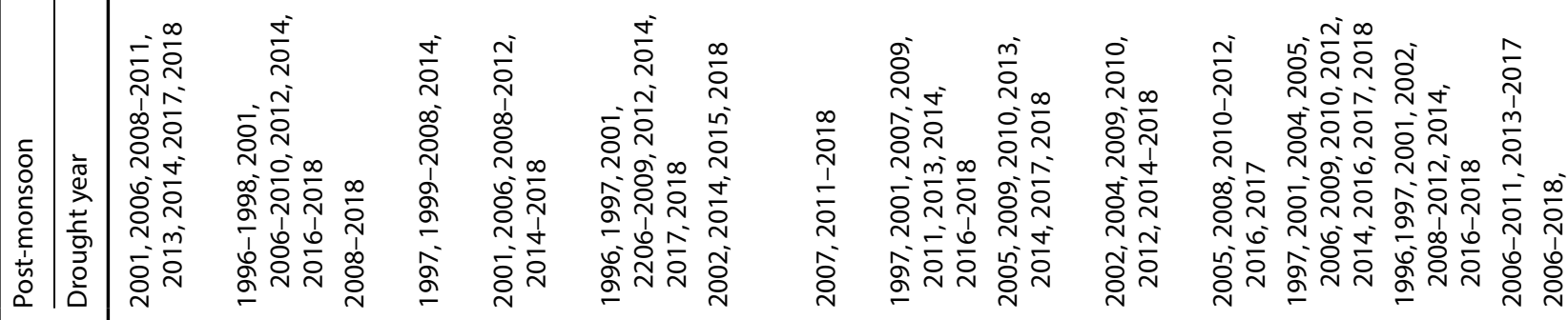

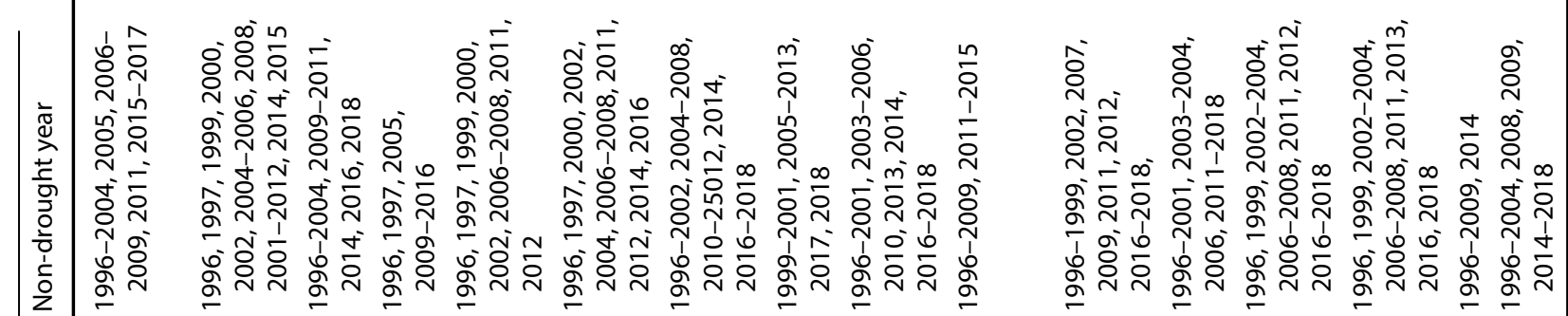

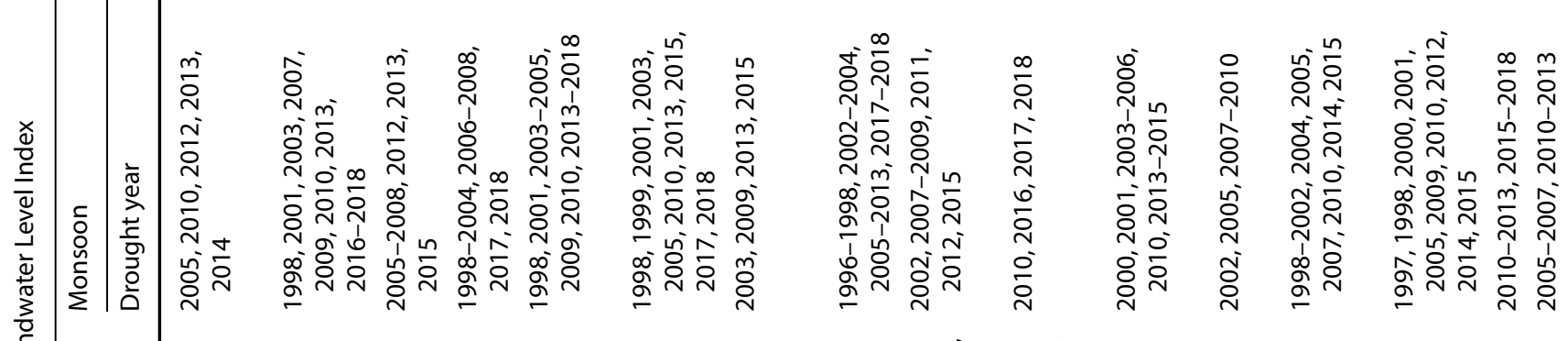

ข้

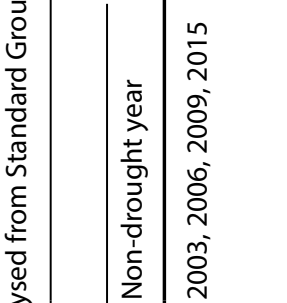

ชิ่

ஓें

实产

ñ

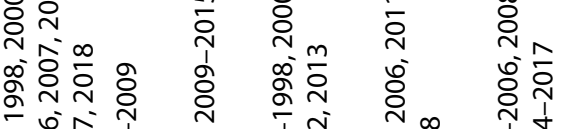

¿ั่

ठั่

ஜั่

芒 ठ্ণ

这.

बूँ

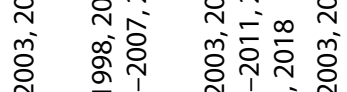

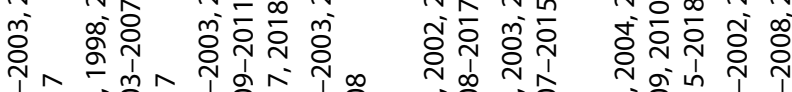

ठำ

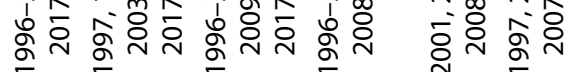

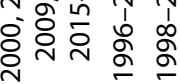

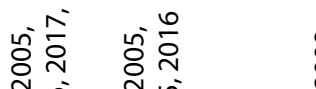

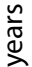

苛

官

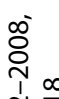

$n \dot{n}$

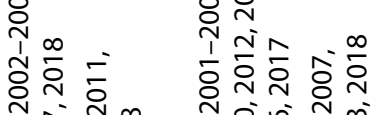

西

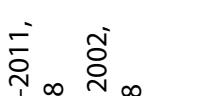

$\frac{1}{2}$

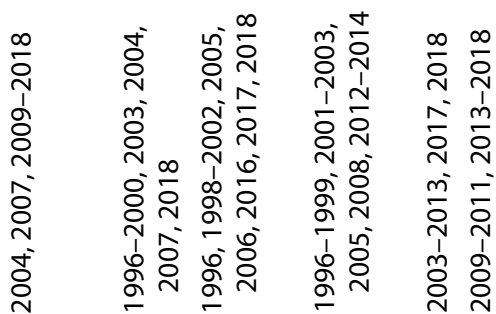

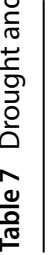

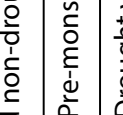
No No

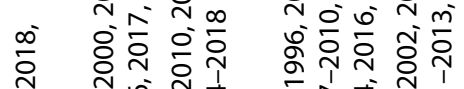

ชิ

సิ

议

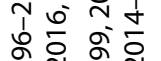

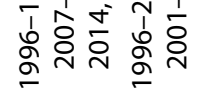

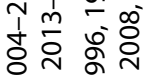

뉴유 율

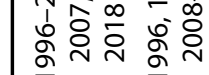

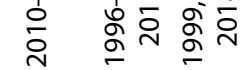

뮴

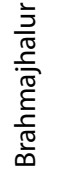

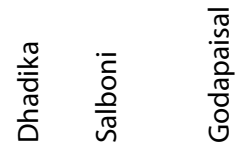

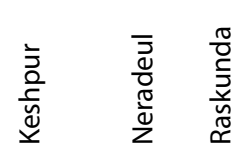

高高咅

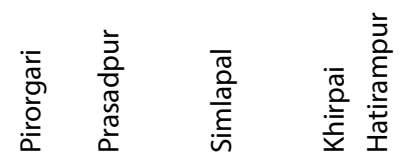




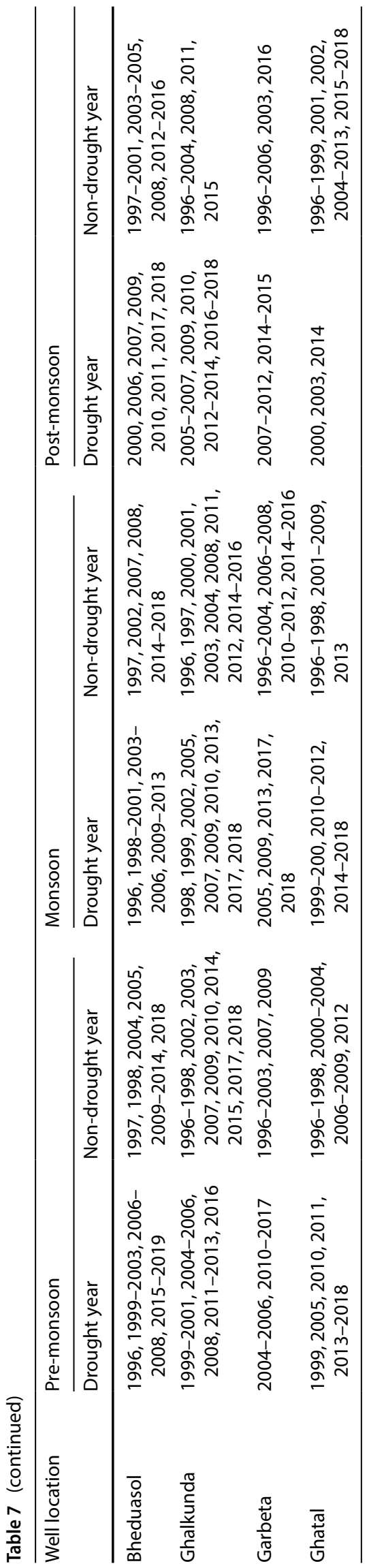

SN Applied Sciences a SPRINGER NATURE journal holding capacity of soil which increases greater run-off and poor aquifer recharge. The groundwater level trend has also been observed using Mann-Kendall test statistics where $25 \%$ of the wells show declining trend in monsoon period, $45 \%$ show declining trend in pre-monsoon period and $60 \%$ show declining trend in post-monsoon period. Extensive pumping of the sub-surface water and drying of the river beds are the main cause of such decline. From the field-level study, the villagers also informed about the water scarcity in the recent years due to lack of precipitation which eventually led to the decline in groundwater level and drying of surface water bodies and giving a threat to food security. Well location at Chandrakona road has been showing higher fluctuation about $6.305 \mathrm{~m}$ which is mainly due to the effect of land use and land cover change and alteration of precipitation dynamics. An increase in the settlement cover here has led to increase in built-up area encouraging overland flow, and replenishment of the aquifer takes longer time. Standard Groundwater Level Index has been calculated to observe the groundwater drought within the study area. Wells located at the populated centres are showing positive values that are greater deviation from the normal depth and are signifying more decline in water level. In 2018, the wells located at the lower middle section mainly faced groundwater drought. Every year this river basin faces extreme meteorological, hydrological and agricultural drought in the month of April and March which sometimes extends to the month of June due to the delayed onset of monsoon. Discharge from the wells does not reach the satisfactory level, and the majority of the wells go dry during the hot and humid summer season [39]. Therefore, a more detailed study to explore the cumulative effects of the trend and pattern of the groundwater quantity and quality is essential. The outcome of the study can be an elementary step to improve the sustainable groundwater management strategy. To mitigate such groundwater problem, managed aquifer recharge (MAR) and aquifer yield testing can be the important solution together with rainwater harvesting techniques. Continuous monitoring of groundwater level and quality is also important to protect and increase the stock of water in the aquifer layers. 
Fig. 22 Map showing Standard Groundwater Level Index of 2018 monsoon season

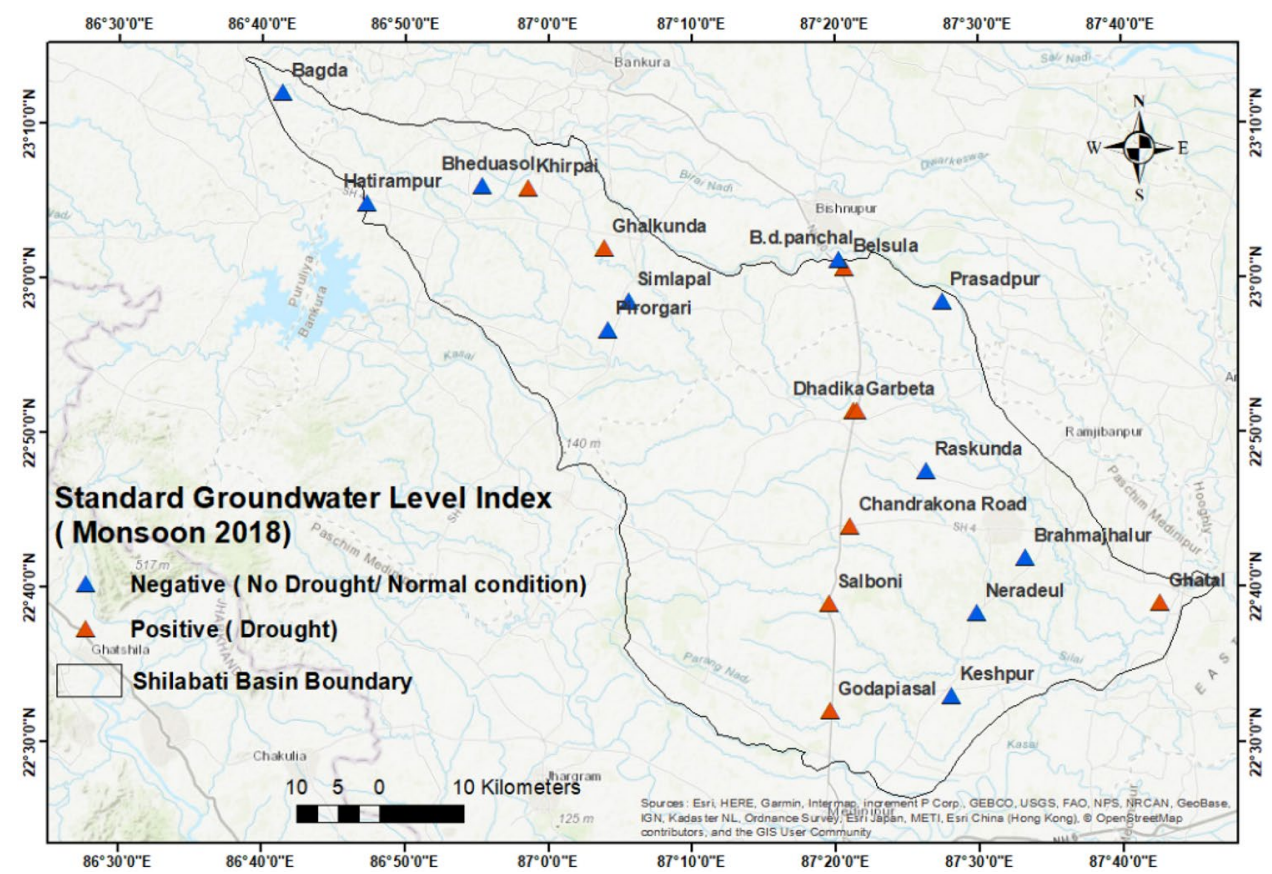

Acknowledgements The authors are showing sincere gratitude to Survey of India (SOI) for providing the Topographical sheets, Central Groundwater Board (CGWB) for providing the seasonal data of wells and Geological Society of India (GSI) for providing essential geological maps. The authors are also acknowledging the Digital Library of School of Water Resources Engineering, Jadavpur University, for allowing to access all the GIS and statistical software.

\section{Compliance with ethical standards}

Conflict of interest On behalf of all authors, the corresponding author states that there is no conflict of interest

\section{References}

1. Green TR (2016) Linking climate change and groundwater. In: Jakeman AJ, Barreteau O, Hunt RJ, Rinaudo JD, Ross A (eds) Integrated groundwater management. Springer, Cham

2. Portmann FT, Doll P, Eisner S, Florke M (2013) Impact of climate change on renewable groundwater resources: assessing the benefits of avoided greenhouse gas emissions using selected CMIP5 climate projections. Environ Res Lett 8:024023. https:// doi.org/10.1088/1748-9326/8/2/024023

3. Engelenburg VJ, Hueting R, Rijpkema S, Teuling JA, Uijlenhoet R, Ludwig $F$ (2017) Impact of changes in groundwater extractions and climate change on groundwater-dependent ecosystem in a complex hydrogeological settings. Water Resour Manage 32:259. https://doi.org/10.1007/s11269-017-1808-1

4. Bloomfield JP, Marchant BP (2013) Analysis of groundwater drought using variant of Standardised Precipitation Index. Hydrol Earth Syst Sci Dis 10:7537-7574. https://doi.org/10.5194/ hessd-10-7537-201

5. Zektser IS, Everett LG (2004) Groundwater resources of the world and their use UNESCO: series on groundwater n.6
6. Doll $P$ (2009) Vulnerability to the impact of climate change on renewable groundwater resources: a global-scale assessment. Environ Res Lett 4:035006. https://doi.org/10.1088/17489326/4/3/035006

7. Gun (2012) Groundwater and global change: trends, opportunities and challenges. France. International Hydrological Programme

8. Wada $Y$ et al (2010) Past and future contribution of global groundwater depletion to sea-level rise. Geophys Res Lett 39(9):L09402. https://doi.org/10.1029/2012gl051230

9. Carmona G, Varela-Ortega C, Bromley J (2013) Supporting decision making under uncertainty: development of participatory integrated model for water management in the middle Guadiana river basin. Environ Model Softw 50:144-157. https://doi. org/10.1016/j.envsoft.2013.09.007

10. Salem GSA, Kazama S, Shahid S, Dey NC (2018) Impacts of climate change on groundwater level and irrigation cost in a groundwater dependent irrigated region. Agric Water Manag 208:33-42

11. Sishodia RP, Skhula S, Graham WD, Wani SP, Garg KK (2016) Bidecadal groundwater level trends in a semi-arid south indian region: declines, causes and management. J Hydrol Reg Stud 8:43-58

12. Tiwari V, Wahr J, Swenson S, Singh B (2011) Land water storage variation over Southern India from space gravimetry. Curr Sci 101(4):536-540

13. Kumar S, Rathnam EV (2019) Analysis and prediction of groundwater level trends using four variations of Mann Kendall test and ARIMA modelling. J Geol Soc India 94:281. https://doi. org/10.1007/s12594-019-1308-4

14. Patra S, Sahoo S, Pulak M, Mahapatra SC (2018) Impacts of urbanization on land use/cover changes and its probable implications on local climate and groundwater level. J Urban Manag 7(2):70-84

15. Pathak AA, Dodamani BM (2019) Trend analysis of groundwater levels and assessment of regional groundwater drought: Ghataprabha River Basin. India Nat Resour Res 28:631. https:// doi.org/10.1007/s11053-018-9417-0 
16. Ganapuram S, Nagarajan R, Sekhar GC (2016) Identification of groundwater drought prone zones in Pedda vagu and Ookachetti vagu watersheds, tributaries of the Krishna River, India. Geocarto Int 31(4):385-407. https://doi.org/10.1080/10106 049.2015 .1047472

17. Bloomfield JP, Marchant BP, McKenzie AA (2018) Changes in groundwater drought associated with anthropogenic warming. Hydrol Earth Syst Sci 23(3):1393-1408. https://doi.org/10.5194/ hess-23-1393-2019

18. Central Ground Water Board, Ministry of Water Resources, River Development and Ganga Rejuvenation, Government of India (2017-2018) Ground Water Year Book-India 2017-2018

19. Das B, Pal SC, Malik S, Chakraborty R (2019) Modeling groundwater potential zones of Puruliya District, West Bengal, India using remote sensing and GIS techniques. Geol Ecol Landsc 3(3):223-237. https://doi.org/10.1080/24749508.2018.1555740

20. Sulaiman NH, Kamarudin MKA, Dasuki A, Amran M, Azaman F, Abidin IZ, Hairoma N (2015) Trend analysis of Pahang River using non-parametric analysis: Mann Kendall's trend test. Malays J Anal Sci 19(6):1327-1334

21. Mann HB (1945) Non-parametric tests against trend. Econometrica 13:163-171

22. Panada A, Sahu N (2019) Trend analysis of seasonal rainfall and temperature pattern in Kalahandi, Bolangir and Koraput districts of Odisha. Atmos Sci Lett. https://doi.org/10.1002/asl.932

23. Sen PK (1968) Estimates of regression coefficient based on Kendall's tau. J Am Stat Assoc 63:1379-1389

24. Gocic M, Trajkovic S (2013) Analysis of changes in meteorological variables using Mann Kendall and Sen's slope estimator statistical test In Serbia. Global Planet Change 100:172-182. https ://doi.org/10.1016/j.gloplacha.2012.10.014

25. Tian W, Cao Y, Ismael A, Stone D, Liang J (2014) Roles of regulated internalization in the polarization of cell surface receptors. In: 2014 Conference of the IEEE engineering in medicine and biology society, pp 1166-1169. https://doi.org/10.3390/w8010011

26. Ghosh KG (2018) Geo-statistical assessment of the intensity, duration, frequency and trend of drought over Gangetic West Bengal, Eastern India. In: Topics in hydrometerology, Theodore V Hromadka II and Prasada Rao, IntechOpen. https://doi. org/10.5772/intechopen.80037

27. Dong G, Zhang H, Moise A, Hanson L, Linag P, Ye H (2016) CMIP5 model -simulated onset, duration and intensity of the Asian summer monsoon in current and future climate. Clim Dyn 46:355. https://doi.org/10.1007/s00382-015-2588-z

28. Shit KP, Nandi AS, Bhunia GS (2015) Soil erosion risk mapping using RUSLE model on Jhargram sub-division at West Bengal in India. Model Earth Syst Environ 1:1-12
29. Census of India (2011) West Bengal, District Statistical Handbook, Paschim Medinapore, Series 20

30. Bui et al (2012) Spatio-temporal analysis of recent groundwaterlevel trends in the red river delta, Vietnam. Hydrogeol J 20:1635. https://doi.org/10.1007/s10040-012-0889-4

31. Vousoughi FD, Dinpashoh Y, Aalami MT, JhaJharia D (2013) Trend analysis of groundwater using non-parametric methods (case study: Ardabil Plain). Stoch Environ Res Risk Assess 27:547. https ://doi.org/10.1007/s00477-012-0599-4

32. Salah MdE, Turki AM, Al-Othman EM (2012) Assessment of water quality of Euphrates river using cluster analysis. J Environ Prot 3(12):1629-1633. https://doi.org/10.4236/jep.2012.312180

33. Central Ground Water Board, Ministry of Water Resources, River Development and Ganga Rejuvenation, Government of India, (2015-2016) Ground Water Year Book of West Bengal and Andaman and Nicobar Islands

34. Vishwajith KP, Sahu PK, Noman Md, Dhekale BS, Narasimhaiah L (2015) Clustering of the districts of West Bengal based on spatial and temporal distribution of groundwater table depth towards effective monitoring and management of the valuable water resources. Nat Environ Pollut Technol 14(3):501-508

35. Tan et al (2020) Drought disaster risks under CMIP5 RCP scenarios in Ningxia Hui Autonomous Regions, China. Nat Hazards. https://doi.org/10.1007/s11069-019-038110

36. Krogulec $E$ (2018) Evaluating the risk of groundwater drought in groundwater-dependent ecosystems in the central part of the Vistula River Valley, Poland. Ecohydrol Hydrobiol 18(1):82-91. https://doi.org/10.1016/j.ecohyd.2017.11.003

37. Ghosh KG (2019) Spatial and temporal appraisal of drought jeopardy over the Gangetic West Bengal, Eastern India. Geoenviron Disaster 6(1):1. https://doi.org/10.1186/s40677-018-0117-1

38. Pan Y, Gong H, Zhou D, Li X, Nakagoshi N (2011) Impact of land use on groundwater recharge in Guishui River Basin, China. Geogr. Sci. 21:734. https://doi.org/10.1007/s11769-011-0508-7

39. Dey KK, Dwivedi VK, Mishra S (2018) Analysis of long-period seasonal variation of temperature for the district of Bankura and Puruliya in a time of climate change. Int J Curr Res 10(11):75495-75497

Publisher's Note Springer Nature remains neutral with regard to jurisdictional claims in published maps and institutional affiliations. 